\title{
The Broken Pitcher
}

\section{A Comedy in One Act}

Heinrich von Kleist

translated by

Bayard Quincy Morgan 
The Broken Pitcher 


\section{IIIIUNC}

From 1949 to 2004, UNC Press and the UNC Department of Germanic \& Slavic Languages and Literatures published the UNC Studies in the Germanic Languages and Literatures series. Monographs, anthologies, and critical editions in the series covered an array of topics including medieval and modern literature, theater, linguistics, philology, onomastics, and the history of ideas. Through the generous support of the National Endowment for the Humanities and the Andrew W. Mellon Foundation, books in the series have been reissued in new paperback and open access digital editions. For a complete list of books visit www.uncpress.org. 


\section{The Broken Pitcher}

\section{A Comedy in One Act}

BY HEINRICH VON KLEIST

TRANSLATED BY BAYARD QUINCY MORGAN

UNC Studies in the Germanic Languages and Literatures Number 31 
Copyright (C) 1961

This work is licensed under a Creative Commons CC BY-NC-ND license. To view a copy of the license, visit http://creativecommons. org/licenses.

Suggested citation: Kleist, Heinrich von. The Broken Pitcher: A Comedy in One Act. Translated by Bayard Quincy Morgan. Chapel Hill: University of North Carolina Press, 1961. DoI: https://doi. org/10.5149/9781469658025_vonKleist

Library of Congress Cataloging-in-Publication Data

Names: Morgan, Bayard Quincy.

Title: The broken pitcher : A comedy in one act / by Bayard Quincy Morgan.

Other titles: University of North Carolina Studies in the Germanic Languages and Literatures; no. 31.

Description: Chapel Hill : University of North Carolina Press, [1961] Series: University of North Carolina Studies in the Germanic Languages and Literatures.

Identifiers: LCCN 61064205 | ISBN 978-0-8078-8031-9 (pbk: alk. paper) | ISBN978-1-4696-5802-5 (ebook)

Classification: LCC PD25 .N6 No. 31 | DCC 832/.6 




\section{PRINCIPAL DATES OF KLEIST'S LIFE}

18 October 1777. Born at Frankfurt an der Oder.

1798. Death of his father.

1792. Army service.

1793. Death of his mother.

1793-4. Participation in the Rhine campaign.

1799. Retired from the army. Study in Frankfurt.

1800. Berlin, post in the ministry of finance.

1801. Work begun on Robert Guiscard (tragedy).

1803. Die Familie Schroffenstein (tragedy).

1803. Guiscard burned (the first act has survived).

1804-7. Königsberg, government service.

1807. Der zerbrochene Krug (comedy). (Complete before this date.)

"Amphitryon (a reworking of Molière, complete before this date).

" Arrest and imprisonment by the French.

1807-9. Dresden, editing magazine "Phöbus."

" Penthesilea (tragedy).

" Das Käthchen von Heilbronn (romantıc drama).

" Die Hermannsschlacht (historic drama).

1810. Prinz Friedrich von Homburg (historic drama).

$" \quad$ Erzählungen.

1811. Erzählungen (a second volume of stories

21 November 1811. Death by suicide. 


\section{INTRODUCTORY}

(Bernd) Heinrich (Wilhelm) von Kleist was born in Frankfort-on-Oder, 18 October 1777. His early education was scanty, and at fifteen he entered the Prussian army, in which he served till 1799. Study of physics in Frankfort followed, but for only three semesters; restlessness of spirit, which remained one of his characteristics, took him to Berlin, Paris, Switzerland, Weimar, Dresden, and again Paris. There, in a fit of despondency, he burned the MS of his drama Robert Guiscard; only the first act has survived. In 1804 he was transferred from Berlin to a government post in Königsberg, where Der zerbrochene Krug was written. Arrested by the French as a spy while on a journey to Dresden in 1807 , he was kept a prisoner for six months in Châlons-sur-Marne, France. On his release he went back to Dresden, where he edited in 1808 a journal called "Phöbus," in which he published his drama Penthesilea and some of his poems. A year later he was in Prague, but not for long. From October 1810 to March 1811 he edited in Berlin the Berliner Abendbläter, in which he opposed Napoleon on the one hand, minister Hardenberg on the other. But fortune was seldom on his side; financial and political difficulties closed in on him; he found no takers for his creative work (Käthchen von Heilbronn, a drama; Michael Kohlhaas and other novellas) ; and his own personality lacked stability. It is a sad fact, which doubtless contributed to his fateful despondency, that Kleist never saw one of his plays on the stage. He saw no way out but suicide, and on 21 November 1811 he went with Henriette Vogel, who had an incurable disease and had agreed to his plan, to Wannsee near Berlin, where he took first her life and then his own.

Only after Kleist's death were the masterpieces of his final period published in an edition of his complete works (1821) supervised by Ludwig Tieck; these included Die Hermannsschlacht, a patriotic drama ostensibly dealing with the defeat of the Roman armies under Varus by the German Arminius (Hermann) in the year 9 A. D., actually however making Varus stand for Napoleon; and Prinz Friedrich von Homburg, the finest of his dramas, which glorified the Great Elector of Prussia. Today the name of Heinrich von Kleist stands among the pioneers of his time, and it is recognized that in many respects he was so far ahead of his contemporaries that it took decades to catch up with him. 


\section{Der zerbrochene Krug}

We are informed in the Selbstschau (autobiography) of Heinrich Zschokke (1771-1848), a once popular writer, that in 1802, when Kleist was visiting him in Bern, he had a French etching hanging on his wall, La cruche cassée. Kleist, Zschokke, and a certain Ludwig Wieland undertook to see who could produce the best work based on this etching, which seeemed to tell a story; Zschokke conceded the victory to Kleist, and indeed Der zerbrochene Krug is regarded as one of the most delightful comedies in German literature.

The germinal motif, which Kleist did not get from the etching, is one of startling originality: the judge is the culprit! And this country judge, appropriately named Adam, who has not too much legal training, but a good deal of mother wit, is not only the supreme figure in the play but one of the most brilliant inventions in theatrical history.

The action of the comedy may hardly be said to follow a plot; certainly the audience can have little doubt at any time of where the guilt lies. Instead of unraveling a tangled skein, Kleist's action consists in pulling the noose tighter and tighter about the valiantly struggling but inescapably inculpated judge, until the latter has no other recourse than his own flying feet.

Some of the comedy is verbal, and in such cases no translation could do full justice to the original. But in the main we have the interplay of character and conduct, and this is not merely German and Kleistian, it is universal.

Kleist's bad luck did not exclude his comedy, which was performed only once during his lifetime, at Weimar under Goethe. Unfortunately Goethe, to whom Kleist's nature was not congenial, pulled the play apart and made three acts of it, thus turning its brisk gallop into a plodding walk; and Weimar had no actor to do justice to Adam, with whom the play stands or falls. It was not until 1844, when a talented comedian gave Judge Adam the kind of interpretation he has to have, that Kleist's comedy found its lasting place in the German theatrical repertoire. No less a master of dramatic writing than Friedrich Hebbel remarked that Der zerbrochene Krug is one of those works whose stage failure meant that the audience had flunked. And he added that since Faistaff no comic figure had been created that was worthy to unloose the shoelaces of Judge Adam. 


\section{PERSONS}

WALter, Circuit Judge

ADAM, Village Judge

LIGHT, Clerk of Court

Dame MaRTha Rull

EvE, her daughter

VEIT, a peasant

RUPRECHT, his son

DAME BRIDGET

A serving man, Bailiff, maids, etc.

The action takes place in a Dutch village near Utrecht; time, the eighteenth century of our era.

Scene: The Courtroom. 


\section{SCENE ONE}

(Adam is sitting and bandaging his leg. Light enters.)

Light. Well, what the devil, tell me now, friend Adam?

Whatever's happened to you? How you look!

ADAM. O well, to stumble all you need is feet.

On this smooth floor, I ask you, where's a stump?

And yet I stumbled here; for each man has

The wretched stumbling block within himself.

LIGHT. What's that you say? That each one has his block-?

ADAM. Yes, in himself.

LigHT. Why, damn it!

ADAM.

What do you mean?

LIGHT. Your name is that of a flighty ancestor,

Who fell right at the very start of things,

And whom that selfsame fall has given his fame;

You're surely not-?

ADAM.

Well?

LIGHT.

Likewise-?

ADAM. I-? I think so-!

Right here it was I took a fall, I tell you.

LIGHT. No figurative fall?

ADAM.

Not figurative.

I guess 'twas no fair figure that I cut.

LigHT. And when did all this happening come to pass?

ADAM. Right now, this moment; I was getting up

From bed. I had the dawn song on my lips, When, crash! I stumbled right into the dawn,

And I'd not yet begun my daily course

Before God made me dislocate my foot.

Light. No doubt it was the left, to boot?

ADAM.

The left one?

LigHT. This solid one here? 
ADAM. Surely.

LIGHT. Righteous God!

That finds as it is the way of sin so hard?

AdaM. The foot! What? Hard! How so?

LIGHT.

The clubfoot?

ADAM.

Clubfoot!

One foot is just as clubby as another.

Light. Not so, my friend! You do your right a wrong.

The right one cannot boast of such a - weight,

And it might sooner try the slippery.

ADAM.

Bosh!

Where one foot ventures out, the other follows.

Light. And what has given your face such a defacement?

ADAM. My face, you say?

LIGHT.

What, you've not faced that yet?

ADAM. Unless I'm lying, no-how does it look?

LIGHT. What, how it looks?

ADAM. $\quad$ Yes, friend.

LIGHT.

Why, horrible.

ADAM. Explain yourself more plainly.

LIGHT.

Well, it's flayed,

A gruesome sight. A piece out of your cheek,

How big? I cannot judge without the scales.

ADAM. The deuce you say!

LIGHT (brings a mirror). Here, look! Convince yourself.

A sheep that with the baying dogs behind it

Must squeeze through thorns won't leave more wool behind

Than you've abandoned flesh, the Lord knows where.

ADAM. Hm! Yes! That's so. It doesn't look so nice.

I see my nose has suffered.

LIGHT.

And your eye. 
ADAM. Oh, not my eye, good friend.

LIGHT.

Why yes, here lies

Crosswise a welt, bloodstained, God is my judge,

A raging farmhand might have dealt the like.

ADAM. That's just the eyebone there. -Well, think of that. And all that happened and I never knew it.

LIGHT. Yes, sir! It's like that on the fighting line.

ADAM. What? Fighting! -With that curséd billy goat

50

Upon my stove I fought, I guess. That's it.

When I had lost my balance, drunk with sleep,

And, hands outstretched, was clawing at the air,

I got hold of the trousers that last night

I'd hung all wet to dry upon the stove.

55

I caught at them, you see, fool that I was,

And thought they'd hold me up, but now the belt

Gave way, and belt and I and trousers fell,

And head first with my forehead down I crashed

Upon the stove, just where that billy goat

60

Sticks out his nose right on the corner there.

LIGHT (laughs). That's good!

ADAM. $\quad 0$ hell!

Light.

The firstest fall of Adam

You ever took in falling out of bed.

ADAM. My soul! - But by the way, what is the news?

LIGHT. Oh yes, there's news, all right! May I be hanged,

I almost had forgot it.

ADAM.

Well?

LIGHT. Make ready for an unexpected visit

From Utrecht.

ADAM. $\quad \mathrm{Oh}$ ?

LIGHT.

The circuit judge is coming.

ADAM. Who's coming? 
LIGHT. Justice Walter, district judge, from Utrecht. He's out inspecting all the district courts, And here he will arrive today

ADAM. Today? Have you your wits?

LIGHT.

As true as I live.

He was in Holla yesterday, reviewed

The court of justice in that border town.

A peasant saw the horses being hitched

To bring his carriage on to Huysum here.

AdAM. Today, from Utrecht, he, the district judge?

Inspecting, eh? The worthy man, who fleeces

His lambs aright and hates such fooleries.

He comes to Huysum just to harry us!

LigHT. If he reached Holla, he'll reach Huysum too.

You'd best beware.

ADAM. Go on!

LIGHT.

I'm telling you.

ADAM. Go on there with your fairy tales, I say.

LIGHT. The peasant says he saw him, what the devil.

ADAM. Who knows who 'twas that blear-eyed scoundrel saw. 85,

Those fellows can't distinguish back from front;

A skull's a face to them, just so it's bald, Put a three-cornered hat upon my stick,

A mantle draped around, two boots beneath-

Such fools will take it to be whom you will.

Light. Well, go on doubting, in the devil's name, Till he comes in that door.

ADAM.

What, he, and enter!-

Without his having breathed a hint to us.

LIGHT. What foolishness! As if 'twas still the same

Inspector as before, Judge Juniper!

It's Walter now who will inspect our court.

ADAM. Suppose it is! Go on, leave me in peace.

The man has taken his official oath 
And practices, like us, according to

Existing edicts and the precedents.

LIGHT. Well, I assure you, yesterday Judge Walter

Appeared in Holla wholly unexpected,

Inspected cashbox and the records kept,

And then suspended both the judge and clerk;

Why? I don't know, but they are out of office.

ADAM. Well, I'll be damned! Was that the peasant's tale?

LIGHT. That and some more-

ADAM.

Eh?

LIGHT.

If you want to know.

For on this very day they seek the judge,

Who's held as prisoner in his own house,

And find him in the granary behind

Strung up there from a rafter of the roof.

ADAM. What do you say?

LIGHT.

Meanwhile some help is brought,

They cut him down, they rub him and they drench him,

And barely into life they bring him back.

ADAM. They bring him back, eh?

LIGHT.

Now his house is sealed,

With depositions sworn and things locked up,

As if he was a corpse before his time,

And now his judgeship is inherited.

AdAM. Well, damn my eyes! - He was a low-lived cur-

Yet honest, for the rest, upon my life;

A chap with whom one could have pleasant hours;

But curséd low-lived, yes, I must admit.

And if today Judge Walter was in Holla,

Poor chap, he got it roundly, never fear.

LIGHT. And only this affair, the peasant said,

Has kept the judge till now from reaching us;

But without fail by noon he would be here.

ADAM. At noon! Good, partner! Now your friendship tells.

You know just how two hands can wash each other.

I know you'd like well to be village judge, 
And you deserve it, too, as well as any.

But this is not your opportunity,

Today I think you'll let that cup pass by.

LIGHT. I, village judge! What must you think of me!

ADAM. You are a lover of effective speech,

And you have learned as much from Cicero

As any at the school in Amsterdam.

Keep your ambition back today, you hear?

No doubt there'll be occasions yet to come

When you can show your skill to good effect.

LIGHT. We two good comrades! Get along with you.

ADAM. At rightful times, you know, Demosthenes

The great was mute. Be guided now by him.

And though I am not King of Macedon,

Still in my way I can be grateful too.

LIGHT. Away with your suspiciousness, I tell you.

Or have I ever - ?

ADAM.

Look, I, for my part,

I follow also that great Greek. You know,

One could in time work out a mighty speech

On public funds and rates of interest;

150

But who would want to phrase such periods?

Light. Of course!

ADAM. Of such reproach I'm wholly free,

In devil's name! And all that is at stake

Is but a prank, perhaps, born of the night

And shunning daylight's meddling rays.

LIGHT.

I know.

AdAm. My soul! No reason, really, why a judge,

When he's not sitting on the judge's bench,

Should walk as gravely as a polar bear.

LIGHT. I say so, too.

ADAM.

Well then, come on, good friend,

And follow me into the registry;

I'll stack the documents a bit, for they,

They lie there like the fallen tower of Babel. 


\section{SCENE TWO}

(A Servant enters. Later: two maidservants.)

SERVANT. God save you, Judge! Inspector Justice Walter

Sends his respects and says he'll soon be here.

ADAM. Well, righteous heavens! Is he done with Holla 165 So early?

SERVANT. Yes, he's here in Huysum now.

ADAM. Hi! Lisa! Greta!

LIGHT.

Quiet there, be calm.

ADAM. I beg you!

LIGHT.

Send him back respectful thanks.

SERVANT. Tomorrow we continue on to Huzzah.

ADAM. What shall I do? What shun? (He reaches for his

clothes.) 170

FIRST MAID (enters). I'm here, sir.

LIGHT. Put on those trousers, will you? Are you mad?

SECOND MAID (enters). Here, at your service, Judge.

LIGHT.

And now your coat.

ADAM (looks around). Is that the District Judge?

LIGHT.

No! Just the maid.

ADAM. My cuffs! My coat! My collar!

FIRST MAID.

First the vest!

ADAM. What? - Coat off! Quick!

LIGHT (to Servant). The District Judge will be

Most welcome here. We shall at once be ready

To have him visit us. You tell him that.

ADAM. In the devil's name! Judge Adam begs to be

Excused.

LIGHT.

You say excused? 
ADAM.

I say excused.

Is he already on his way?

SERVANT.

$\mathrm{He}$ is

Still at the inn. He's waiting for the smith;

The carriage came apart.

ADAM.

That's good. My greeting.

A lazy smith. Present him my excuses.

Say I have nearly broken neck and legs;

You see, it is a fright, the way I look;

And every fright affects me like a purge.

Say I am sick.

LIGHT. Have you your wits about you?

You tell the judge we shall be glad to see him.

- (To Adam.) Will you?

ADAM.

Oh, hang it!

LIGHT.

What?

ADAM.

It's just as if I'd had a dose of salts!

The devil take me,

190

Light. That's all you need, to let him smell a rat.

AdAM. Hi, Margareta! Bag of bones! Hi Lisa!

Вотн MAIDS. Why, here we are. What is it?

ADAM.

Go, get out!

Fetch cheese and ham, and sausage, butter, beer,

From out the registry! and make it quick! -

Not you. The other. - Booby! I mean you!

-God's lightning, Margret! Lisa, you, the cowgirl,

Go, get it! (Exit First Maid.)

SECOND MAID. Speak, if you'd be understood!

ADAM. Shut up now, you! Get out! Get me my wig!

March! From the bookcase. Lively! Go!

(Exit Second Maid.)

LIGHT (to Servant). I hope your lord, the worthy District Judge,

Has met with no misfortune on his journey? 
SERVANT. Oh, well, we capsized in the narrow pass.

ADAM. Ouch! Oh, my foot's all skinned! My boots will not-

LIGHT. Well now, in heaven's name! Capsized, you say? 205 But still no further harm-?

SERVANT. Nothing important.

My master sprained his hand a little bit.

The shaft broke off.

ADAM.

I wish he'd broken his neck!

Light. What, sprained his hand! Well, well! Has the smith come?

Servant. To mend the shaft, yes.

LIGHT.

What?

ADAM.

You mean the doctor.

LIGHT. What?

SERVANT. For the shaft?

ADAM. $\quad \mathrm{Oh}, \mathrm{bosh}$ ! To bind his hand.

SERVANT. Your servant, sir.-I think these chaps are mad. (Exit.)

LIGHT. I meant the smith.

ADAM. $\quad$ You give yourself away.

Light. How so?

AdAM. You are embarrassed.

LIGHT.

What!

(The First Maid enters.)

ADAM.

Hey! Lisa!

What's that you've got?

First MaId.

Why, Brunswick sausage, sir.

ADAM. No, that's my guardian stuff.

LIGHT.

What, I embarrassed! 
ADAM. They should be brought back to the registry.

FIRST MAID. The sausage?

ADAM.

Sausage! Bosh! These wrappers here.

LIGHT. 'Twas a misunderstanding.

SECOND MAID (enters). Judge, your wig,

I don't know where it is, not in the bookcase.

ADAM. Why not?

SECOND MaID. Hm! Since you-

ADAM.

Well?

SECOND MAID.

Why, at eleven-

Last night-

AdAM. Well? Will you speak?

SECOND MAID.

You came, you know,

Without your wig into the house, remember.

ADAM. What, I, without my wig?

SECOND MAID.

Indeed you did.

And here is Liz, to testify the same.

225

The other one's at Utrecht in the wig shop.

ADAM. You say-?

FIRST MAID. Yes, on my honor, sir, Judge Adam!

You were bald-headed, sir, when you returned;

You said that you had fallen, don't you know?

I had to wash the blood stains off your head.

ADAM. Impertinent thing!

FIrst MAID.

As I'm an honest girl.

ADAm. Shut up, I say, there is no truth in it.

LIGHT. What, yesterday you got that wound?

ADAM.

Today.

The wound today and yesterday the wig.

I wore it, powdered white, upon my head,

And with my hat I took it off, my word, 
By error when I stepped into the house.

No telling what it was she may have washed.

-Go to the devil, that's where you belong!

Go to the registry! (Exit First Maid.) You, Margret, go

And ask the Verger if he'll lend me his;

Tell him the cat, the dirty pig, had littered

This morning in my wig. All filthied up

It lay beneath my bed, I now recall.

Light. The cat? What say? Are you-?

ADAM.

True as I live.

Five kittens, black and yellow; one is white.

The black ones, I shall drown them in the river.

What can one do? Would you like one to keep?

LIGHT. What, in your wig?

ADAM.

The devil take me else.

For I had hung the wig, as usual,

Upon a chair, when I got into bed,

But in the night I hit the chair, it falls-

LiGHT. The cat then takes it in her jaws-

ADAM.

My soul-

LIGHT. And bears it under the bed to bear her young.

AdAM. Her jaws? No-

255

LIGHT.

No? How else?

ADAM.

The cat? Oh, bosh!

Light. No? Was it you, perhaps?

ADAM.

My jaws! I think-!

I kicked it under with my foot today,

On seeing it.

LIGHT. $\quad$ Oh, good.

ADAM. These wretched beasts!

They copulate and litter where there's room.

SECOND MAID (giggling). Then shall I go? 
ADAM. Yes, do, and take my greeting

To cousin Bombazine, the Verger's wife.

I'll send the wig undamaged back to her

This very day - to him you need say nothing.

You understand?

SECOND MAID. I'll carry out your wish. (Exit.)

\section{SCENE THREE}

ADAM. I foresee nothing good at all, friend Light.

LigHT. Why that?

ADAM. My life is all askew today.

And isn't this a court day?

LIGHT. Yes, it is.

The plaintiffs are already at the door.

ADAM. - I dreamt a plaintiff had laid hold of me And dragged me to the judge's seat; and I, I sat there all the same upon the bench, And scolded, skinned and ruffianed me down, And sentenced my own neck into the irons.

Light. Condemned yourself?

ADAM. As I'm an honest man.

We two then grew to one, and took to flight, And had to spend the night among the pines.

Light. Well? And the dream, you think -?

ADAM. The devil take it.

And if it's not the dream, some deviltry,

I don't know what, is in the wind for me!

LigHT. Oh flabby fear! Just heed established rules.

As long as the inspector's visiting,

And hand out from your bench impartial justice,

In order that your dream of judge dismissed

Be not fulfilled, though in another way. 


\section{SCENE FOUR}

\section{(District Judge Walter enters.)}

WALter. God save you, Justice Adam.

ADAM. Well, how welcome!

Most welcome, worthy sir, here in our Huysum!

Who could have, righteous God, who could have thought

That we should have such joyous visitation.

No dream as late as eight o'clock this morning

Might have aspired to such a lofty fortune.

WALTER. I'm somewhat overprompt, I know, and must

Upon this journey, in our public service,

Be satisfied, if my good hosts dismiss

$\mathrm{Me}$ in the end with well-disposed salute.

Meanwhile, as touching my own salutation,

My wish is to be kind, right from the start.

The high tribunal of our land at Utrecht

Seeks to improve law practice in the country,

Which does appear in many ways defective;

Abuses may expect a stern rebuke.

But my concern upon this trip is not

So stern as yet; I am to see, not punish,

And though I find things not as they should be,

I shall be glad to find them bearable.

ADAM. In truth, such noble thinking must be praised.

305

Your Honor will at times, I have no doubt,

Find fault with our time-honored legal use;

And though it's valid in these Netherlands

And has been since the time of Charles the Fifth:

What cannot be invented by the mind?

The world, our proverb says, grows ever wiser,

And all men read, I know, Sam Pufendorf;

But Huysum is a small part of the world,

Which cannot hope for more nor less than just

Its proper share of universal wisdom.

Give kind instruction to our justice here

And be assured, Your Grace, you will have scarce

So much as turned your back on it again,

When it shall to the uttermost content you; 
But should you find our office here today

As you would wish, my soul, 'twould be a wonder,

Since it but vaguely guesses what you want.

WALTER. There's lack of regulations, yes. Or rather,

There are too many, we shall have to sift them.

ADAM. Yes, with a mighty sieve. Much chaff! much chaff! 325

WALTER. And you're the Clerk of Court?

LIGHT.

I am Clerk Light,

At service of Your Honor. It is now

Nine years that I have been here in this court.

ADAM (brings a chair). Be seated.

WALTER.

Never mind.

ADAM.

You've come from Holla.

WALtER. Two leagues or less-How is that known to you? 330

ADAM. What, how? Your Honor's man-

LIGHT.

A peasant told us;

Who just this minute came to town from Holla.

WALTER. A peasant?

ADAM.

At your service.

WALTER. -Yes! In Holla

A quite unhappy incident took place,

Which has disturbed in me the cheerfulness

335

That should go with us when on duty bound.-

No doubt you have had news of this affair?

ADAM. And is it true, Your Honor, that Judge Pfaul,

On suffering arrest in his own house,

Surrendered to the folly of despair

340

And hanged himself?

WALTER.

And made the evil worse.

What only seemed disorder and confusion

Now gets the aspect of embezzlement,

Which Holland's law, you know, no longer spares.-

How many funds have you? 
ADAM.

Five, please Your Honor.

WALTER. What, five you say? I thought-And money in them? 'Twas my belief you had but four-

ADAM. Your pardon!

Recall the fund for inundations of the Rhine.

WALTER. The fund for inundations of the Rhine!

But now the Rhine is free from inudation, 350 And so collections are not being mâde.

-Tell me, is this the day for holding court?

ADAM. You mean-?

WALTER.

What?

LIGHT. Yes, the first day in the week.

WALTER. So then that little crowd I saw just now

Outside your door, were they-

355

ADAM.

They probably-

LIGHT. They are the plaintiffs who've already gathered.

WALTER. Good. That's a circumstance much to my liking.

I beg that you'll admit these people now.

I will attend your session; thus I'll see

What usages are practised here in Huysum.

360

We'll do the registry, the several funds

Hereafter, when the matter is concluded.

ADAM. As you command. -The bailiff! Hey! Hanfriede!

\section{SCENE FIVE}

(The Second Maid enters.)

SECond MAID. A greeting from the Verger's wife, Judge Adam;

Glad as she'd be to lend the wig365

ADAM.

What? Not?

SECOND MAID. She says they're having morning prayers today;

The Verger has one wig upon his head,

The other one she finds unfit to use,

And it must go to the shop this very day. 
ADAM. Oh hell!

SECOND MAID. As soon as he comes back again,

The Verger, she will send his wig at once.

ADAM. Upon my honor, please Your Grace-

WALTER.

What is it?

ADAM. An accident, most curséd, has deprived Me of both wig:s I own. And now a third, That I had hoped to borrow, fails me too: 375

Bald-headed I shall have to hold my court.

WALTER. Bald-headed!

ADAM. $\quad$ Yes, as God is good! And though

Without my wig's assistance I am much

Embarrassed to retain my dignity,

-Or else I'd have to try out on the farm, And ask my tenant there-?

WALTER.

Out on the farm!

Is there no other person in the place-?

ADAM. No, for a fact-

WALTER.

The minister, perhaps.

ADAM. The minister? $\mathrm{He}-$

WALTER.

Or the teacher.

ADAM. No,

Since tithes were done away, Your Grace,

Which in my office I have helped achieve,

I can no longer count on their assistance.

WALtER. Well, Village Judge? Well? And your session day? Will you then wait until your hair grows out?

ADAM. If you permit, I'll send out to the farm.

WALTER. How far is that from here?

ADAM.

Oh well, perhaps

Not half an hour. 
WALTER. What, half an hour to wait?

And yet it's past the time for court to start.

Get on! For I must reach Huzzah today.

ADAM. Get on! Oh-

WALTER. Well, put powder on your head!

In the devil's name, where did you leave your wigs?

-Come, do as best you can. I am in haste.

ADAM. That too.

BAILIFF (enters). Here is the bailiff!

AdAM.

Can I offer

A tasty bite to eat, with Brunswick sausage,

A glass of cordial too, perhaps-

WALTER.

No thanks.

ADAM. No trouble!

WALTER.

Thanks, I said, I've had some food.

You go and use the time, I need it too

To jot some things down in my little book.

AdAm. Well, if you so command-Come, Margareta!

WALTER. You've had a nasty injury, Judge Adam.

405

What, did you fall?

ADAM.

A truly murderous fall

I took this morning, getting out of bed:

You see, Your Honor, 'twas a wretched crash

Into the room; I thought, into my grave.

WALTER. I'm sorry for it. - Surely it will not

Have consequences?

Adam. $\quad \mathrm{No}$, I think not. Nor

Shall it impede me in my duty's course.-

Your leave!

WALTER. Go, go!

ADAM (to the Bailiff). Call in the plaintiffs-March!

(Adam, the Maid, and the Bailiff go out.) 


\section{SCENE SIX}

(Dame Martha, Eve, Veit, and Ruprecht enter. -Walter and Light in the background.)

MARTHA. 0 pitcher-smashing rabble that you are!

You'll smart for that, you will!

VEIT.

Just you be quiet,

Dame Martha! All that shall be settled here.

MARTHA. O surely. Settled. See him. The smart talker.

The pitcher here, my broken one, all settled.

Who'll settle here for me my settled jug?

Here 'twill be settled-that my jug remains

420

Settled for good. For such a settlement

I wouldn't yet give up these fragments here.

VEIT. If you can demonstrate your right, I've said

I will replace it.

Martha. $\quad$ You'll replace my jug.

If I can demonstrate my right, replace it. 425

You place the jug somewhere, just try it once, Just place it there upon the shelf! Replace it!

This jug, that has no leg to stand upon,

Nothing to lie or sit on, you'd replace!

VEIT. You heard me! Why revile? Can one do more?

If one of us it was that broke the jug,

You shall be compensated.

Martha.

Compensated!

As if one of my hornéd beasts was talking.

What, do you think that justice is a potter?

And if these mighty judges came and tied

435

An apron on and took it to the kiln,

They might put something other in the jug

Than compensation. Nonsense, compensation!

RUPRECHT. Ignore her, father. Heed my words. That dragon!

It's not the broken pitcher gets her sore, 440

It is the wedding that's been broken up,

And by main force she thinks it can be patched 
But I will put my foot down here, besides:

I will be damned if ever I wed the slut.

MARTHA. Conceited ass! I patch the wedding up!

That wedding isn't worth the patching-wire,

Not worth a single fragment of the jug.

And if the wedding stood here all ashine,

As yesterday my jug stood on the shelf,

I'd take it by the handle even now

450

And yelling smash it on his silly head;

But these are fragments I'd not care to patch!

I patch them!

EVE.

Ruprecht!

RUPRECHT.

Eve.

RUPRECHT. Out of my sight!

Eve.

Oh listen, I implore you.

RUPRECHT. O dissolute-! I won't say what you are.

455

EvE. O let me whisper just a word-

RUPRECHT.

No, nothing!

EvE. - You're going to join your regiment now, Ruprecht:

Who knows, when once you start to bear a musket,

If ever again I'll see you in my life.

It's war, remember, war to which you go:

Will you then part from me with such a grudge?

RUPRECHT. Grudge? No, may God forbid, that's not my will.

God grant you so much happiness as $\mathrm{He}$

Can spare. But if I should return from war

In health, and with a body strong as steel,

And lived in Huysum to be eighty years,

Then to my dying day I'd say: you slut!

You'll swear you're that, you know, before the judge.

Martha (to Eve). Away! What did I tell you? Will you even

Hear such abuse besides? The corporal,

That is your man, the worthy Woodenleg, 
Who bore his staff of rank there in the army, And not this gaping fool, who turns his back

To get the staff laid on. We have today

Engagement, wedding; if 'twas christening too,

I wouldn't mind, and burial I'll endure,

When first I've whittled down the prideful comb

That swells enough to smash my pitchers.

Eve.

Mother!

Forget the jug! Let me go see in town

If there's a skillful handicraftsman there

480

To glue the pieces to your satisfaction.

But if the jug is gone, then take my bank,

My savings bank, and buy yourself another.

Who would, just for a jug of earthenware,

And if it was as old as Herod's time,

485

Make such a fuss, cause such unhappiness.

Martha. You show how much you know. How would you like

To wear the wooden necklace, and in church

Do public penance when next Sunday comes?

Your good repute was in this very jug, 490

And with it that was smashed in sight of all,

Though not in sight of God, of me and you.

The judge there is my craftsman; what we need

Is executioner, with block and whiplash,

And all the rabble flaming at the stake,

To burn our honor back to spotless white

And put the glaze back on this jug again.

\section{SCENE SEVEN}

(Adam enters in his robes, but without a wig.)

ADAM (aside). It's Evie! Well! And that square-built young scamp,

That Ruprecht! What the deuce! The whole caboodle!

- They won't accuse me to my very self?

EVE. O dearest mother, come now, I beseech you,

Let us be gone from this unhappy room! 
ADAM. Say, clerk! What have these people on their mind?

LigHT. How should I know? Much noise and little worth.

A pitcher has been broken, I am told.

ADAM. A pitcher! Hm! Well! -Well, who broke the pitcher?

LIGHT. Who broke the pitcher?

ADAM.

Yes, I'd like to know.

LIGHT. My soul, sit down: no doubt you will be told.

ADAM (furtively). Evie!

EVE (similarly).

Go 'way.

ADAM.

One word.

Eve.

I will hear nothing.

ADAM. What is all this?

Eve.

I tell you, go away.

ADAM. Evie! I beg you! What does all this mean?

EvE. If you don't stop-! I tell you, let me be.

ADAM (to Light). No, friend, now listen, this I cannot take.

My wounded shin is making me feel sick;

You take the case, I want to go to bed.

515

Light. To bed-? You would-? I think you've lost your mind.

ADAM. No, hang it all. I know I'll have to vomit.

Light. I think you're really mad. Did you just come-?

-All right then. Tell Judge Walter your intent.

He may permit. - What in the world's the matter? $\quad 520$

ADAM (again to Eve). Evie! I beg of you! By all the wounds!

What is this case you bring?

Eve.

You'll soon find out.

ADAM. Is it the jug there that your mother holds,

Which I, as far-?

Eve.

Yes, just that broken jug.

ADAM. And that is all? 
EvE. That's all.

ADAM.

All? Surely, all?

EvE. I tell you, go away. Leave me in peace.

ADAM. Look out, by God, be wise, I caution you.

EvE. $O$ impudence!

ADAM. In the certificate

The name in full is written, Ruprecht Timpel.

I have it ripe and ready in my pocket;

You hear it crackle, Evie? This you can,

Upon my word, next year come back and get,

Can cut your mourning apron, and your bodice,

When you have heard: your Ruprecht in Batavia

Has croaked-I don't know of what fever,

535

Say yellow, scarlet; maybe something fishy.

WALTER. Don't talk so with the parties, Justice Adam,

Before the session! Sit here, question them.

ADAM. What does he say? -What does Your Grace command?

WALTER. What I command? -I told you that quite plainly:

Don't speak in secret thus before the session

In words of double meaning with the parties.

This is the seat that now befits your office;

An open hearing is what I expect.

ADAM (to himself). Curses! I cannot quite make up my mind-!

-I heard a crash just as I took my leave-

LIGHT (prodding him). Well, Judge! Are you-?

ADAM.

What, I?'Pon honor, no!

I'd hung it carefully upon the thing,

And must have been an ox-

LIGHT.

What?

ADAM.

What?

LIGHT.

I asked you-!

ADAM. You asked if $\mathrm{I}-$ ? 
LiGHT. If you are deaf, I asked you.

His Honor yonder called your name just now.

ADAM. I thought-! Who calls?

LIGHT.

The court inspector there.

AdAM (to himself). Hell! Devil take the thing! Two ways there are,

My soul, no more, and now it's bend or break.

Al once! At once! At once! What would Your Grace? 555

Shall I begin the trial now?

WALTER. It's strange you're so distracted, Judge. What ails you?

ADAM. - My word! Forgive. A guinea hen of mine

I bought of one who sailed from India

Has got the pip: I don't know how to cram it,

560

And merely asked the girl for her advice.

I am a fool, you see, in things like this,

And I am used to call my chicks my children.

WALTER. Here. Sit. Now call the plaintiff, ask him questions.

You, Mr. Clerk, will write the record down.

565

ADAM. And does Your Honor wish the trial held

According to the set formalities,

Or as it has been usual in Huysum?

WALTER. According to the law's formalities,

As usual in Huysum, nothing else.

570

ADAM. Good, good. I shall contrive to serve you well.

All ready, Mr. Clerk?

LIGHT.

I'm at your service.

ADAM. - 0 well then, Justice, take your fated course!

The plaintiff may step up.

MARTHA.

Here, Village Judge!

ADAM. Who are you?

MARTHA. Who-?

ADAM.

You.

MARTHA.

Who I-? 
ADAM. Who you are!

Your name and rank, your dwelling, and so forth.

MARTHA. I think you're jesting, Judge.

ADAM.

I jesting? Bosh!

I'm sitting here in Justice' name, Dame Martha,

And Justice has to know just who you are.

LIGHT (in subdued voice). 0 drop that strange inquiry, Judge-

MARTHA.

You look

Into my windows every Sunday morning,

When going to your farm.

WALTER.

You know the woman?

ADAM. She lives here round the corner, please Your Grace, Just where the footpath leads one through the hedges;

A castellan's widow, now a midwife here.

But honest, for the rest, and well reputed.

WALTER. Well, Judge, if you're so well informed of her,

Then questions such as these are not required.

Just put her name down in the record book

And write beside it: well known to the Court.

ADAM. Ah ha. You shun too much formality.

Clerk, do exactly as His Grace commands.

WALTER. Now ask about the matter of complaint.

ADAM. Oh, now I should-?

WALTER.

Yes, find the matter out!

ADAM. That, please you, is likewise a jug.

WALTER.

What? Likewise! 595

AdAM. A jug. A jug, no more. Put down a jug,

And write beside it: well known to the Court.

Light. What, Judge, upon my random supposition

You would not-?

ADAM.

If I bid you, on my soul,

Then write it. Is it not a jug, Dame Martha? 
MARTHA. Why yes, this jug-

ADAM.

MARTHA.
You see.

This broken jug-

ADAM. Pedantic scrupulousness-

LIGHT.

I beg your pardon-

ADAM. And then who broke the jug? No doubt that rascal-?

MARTHA. Yes, he, that rascal there-

ADAM (aside).

That's all I need.

RUPRECHT. That is not true, Your Honor!

605

ADAM (aside).

Come, on your toes, old Adam!

RUPRECHT. She's lying in her throat-

ADAM. Be silent, dolt!

You'll put your own throat soon enough in irons.

-Put down a jug, then, Clerk, as I have said,

Together with the name of him who broke it.

This matter will be cleared up right away.

WALTER. What, Judge! Why, what a violent procedure.

Adam. How so?

LIGHT. Will you not formally-?

ADAM. Not I!

Your honor doesn't like formalities.

WALTER. Judge Adam, if you do not know the way

To introduce a well conducted trial,

615

This is no time nor place to teach you that.

If you've no other way to deal out justice,

Then step aside: perhaps your Clerk knows how.

ADAM. Pardon! I followed custom here in Huysum;

For thus Your Grace commanded me to act.

620

WALTER. What, I-?

ADAM. Upon my word! 
WALTER.

I ordered you

To deal out justice here as law prescribes;

And laws in Huysum, so I thought, must be As elsewhere in the United Netherlands.

ADAM. Not so, Your Honor, no, I must submit.

For here we do possess, with your permission,

Peculiar statutes of our own in Huysum,

Not written down, I must confess, and yet

To us transmitted by approved tradition.

And from these forms, I'm bold enough to hope,

630

I've not diverged today by jot or tittle.

However, in your other form I am

At home, as it is practised through the land.

Do you demand the proof, well then, command me!

I can dispense the law now so, now so.

WALTER. You put a bad construction on my words.

So be it. Start the case from the beginning.-

ADAM. 'Pon honor. Mark, you shall be well content.

-Dame Martha Rull! Present now your complaint.

MARTHA. You know the cause of my complaint, this jug; 640

Yet grant me grace, before I make report

What happened to the jug, that I describe

What once it was to me.

ADAM. You have the floor.

MARTHA. You see this jug here, worthy gentlemen?

You see this jug?

ADAM.

0 yes indeed, we see it.

MARThA. No, all you see, beg pardon, is the pieces;

The fairest of all jugs is smashed to bits.

Right here upon this hole, where now there's nothing,

The states of the United Netherlands

Were handed over to the Spanish Philip.

650

Here in his robes stood Emperor Charles the Fifth;

Of him all you see standing is his legs.

Here knelt King Philip, and received the crown:

$\mathrm{He}$ 's in the jug now, all but his backside, 
And even that has got a sorry blow.

Two cousins there were weeping-queens they were,

The Queen of France and she of Hungary-

The tears out of their eyes; and when you see

The one still raise the kerchief in her hand,

It is as if she wept at her own fate.

660

Here in the retinue is Philibert,

The blow at whom the Emperor received,

And leans upon his sword; now he must fall

As well as Maximilian: the scoundrel!

The swords beneath them have been knocked away.

Here in the center, with his holy mitre,

There stood once an Archbishop, he of Arras;

But him the devil's got with hide and hair,

His shadow only falls long on the pavement.

Here stood around the bodyguard behind

With halberds, closely thronged, and stabbing spears;

And houses, see, on Brussels' market place.

Here peeps a curious head out of the window:

But what he sees there now, I do not know.

ADAM. Dame Martha! Let the shattered treaty go,

If it is lacking meaning here.

The hole concerns us-not the provinces

That were transferred where yonder hole is now.

MARTHA. Not so! The beauty of the jug does have some meaning.-

This jug was won as spoils by Childerich,

The kettle mender, when our Lord of Orange

Fell upon Briel with all his water rats.

A Spaniard there had filled the jug with wine

And had it at his lips when Childerich

Came from behind and struck the Spaniard down,

685

Took up the jug and drained it, and went on.

ADAM. A worthy water rat.

MaRTha.

The jug then came

Into the hands of Feargod, the grave digger;

He drank but thrice from it, the sober man, And even then the wine was mixed with water.

680 
The first time was when he at sixty years

Wedded a youthful wife; then three years later,

When she had happily made him a father;

And after she had borne him fifteen more,

He drank a third and last time when she died.

ADAM. Good. Not so bad that, either.

MARTHA.

Now the jug

Came to Zachaeus, tailor in Tirlemont,

Who told my husband with his very lips

What I am now about to tell to you.

He cast, one time when French were plundering,

700

The jug with his belongings out the window,

Jumped too and broke his neck, the awkward chump,

And yet this earthen jug, this jug of clay,

Fell square upon its base and was unhurt.

ADAM. Come to the point, Dame Martha! To the point!

MaRTHA. Then when the fire broke out in sixty-six,

My husband owned it then, God rest his soul-

ADAM. The devil! Woman! Will you never be done?

MARTHA. - If I've no leave to tell my tale, Judge Adam,

Then I am useless here, then I will go

And seek a court to hear what I would say.

WALTER. Yes, you should speak; but not of foreign things,

Remote from your complaint. If you depose

That yonder jug was dear to you, we know

As much as we require to judge the case,

MARTHA. How much you may require to judge the case,

I do not know and will not now inquire;

But I know this, that to prefer complaint

$I$ must have leave to tell you what about.

WALTER. All right. Have done. What happened to the jug? 720

What happened to your pitcher in the fire

Of sixty-six? Will you please tell us that?

MARTHA. Why, by your leave, good gentleman, just nothing,

No, nothing harmed the jug in sixty-six. 
The jug stayed whole, whole in the midst of flames, And from our house's ashes I drew out The jug, high glazed, the following day, as bright As if 'twas pulled fresh from the potter's oven.

Walter. All right. We know your pitcher now. We know 730

What happened to the jug, and what did not.

What else is there to say?

MARTHA. Well, look, this jug,

Worth when it's broken just as much as one

Fit for a lady's mouth, and not too poor

To wet the lips of her, our noble Regent, 735

This jug, you worthy judges, both of you, This jug was broken by that rascal there.

ADAM. Who?

MARTHA. He, that Ruprecht there.

RUPRECHT. That is a lie,

Your Honor.

ADAM. Silence, till we question you.

Before this day is done you'll have your turn.

- Have you recorded this, Clerk Light?

LIGHT.

0 yes.

AdAM. Relate the happenings to us, Dame Martha.

MARTHA. 'Twas at eleven yesterday-

ADAM.

What time?

MARTHA. Eleven.

ADAM.

In the morning?

MARTHA.

Pardon, evening-

I was in bed, about to quench the light,

When noisy words of men, a tumult loud, Within the distant chamber of my daughter, As if the foe was breaking in, alarmed me.

I hurried down the stairs, and then I found The bedroom door had been burst in by force, Abusive speeches raged against my ears, 
And now when I light up the scene before me, What do I find, Your Honor, do you think?

I find this jug in pieces on the floor,

A piece of it is flung in every corner,

My daughter wrings her hands, and he, that lout,

$\mathrm{He}$ storms like mad in the middle of the room.

ADAM. By thunder!

MARTHA.

ADAM.

\section{What?}

How now, Dame Martha?

MARTHA.

I felt as if, in such a rage I was,

Ten extra arms was growing out, and each

Was armed just like a vulture with its claws.

I challenged him to tell me by what right

He came there late at night, and in a rage

Was smashing up the pitchers of the house:

And he, the answer that he made, just guess!

Such impudence! Such bold rascality!

I'll see him on the wheel, or else myself

I'll never lay in patience on my back:

He said it was another man that knocked

The pitcher off the shelf-another, bless you,

Who barely had escaped from out the room;

-And heaped abuse upon my daughter here!

ADAM. O! artful shifts-and then?

MARTHA.

Upon that speech

I looked a question at the girl; she stood

Just like a corpse, so white, and I said, 'Eve!'-

775

Then she sat down; 'was it another man?'

I asked. And "Joseph, Mary," she cried out,

"What are you thinking, Mother?"-'Speak! Who was it?"

"Who else," says she-and who else could it be?

And swore to me that it was he who did it.

Eve. What did I swear to you? What have I sworn?

I swore no word, not one-

MARTHA.

Eve! 
Eve.

No! You're lying-

RUPRECHT. You hear that.

ADAM.

Curséd dog, now hold your tongue,

Unless you want this fist to plug your jaws.

You'll have a later chance, not now.

785

MARTHA. You didn't say-

Eve.

No, Mother! That is false.

I will admit it cuts me to the heart

That I must now declare this publicly:

I took no oath at all, swore nothing, nothing.

ADAM. Now children, have some sense.

790

LIGHT.

This is peculiar.

MARTHA. You didn't tell me, Eve, as certain sure-?

You didn't call on Joseph and on Mary?

Eve. Not with an oath! Not sworn to! This I swear,

And now I call to witness Joseph, Mary.

ADAM. Well, people! Well, Dame Martha! What behavior! 795

How you intimidate this poor young thing!

Now when this maiden here will have recalled,

Remembered calmly just what did take place,

-I say, what took place in her room, and what,

Unless she speaks aright, can still take place:

800

You watch, she'll testify just as before,

No matter whether with an oath or not.

Let Joseph go unnamed, and Mary too.

WALTER. No, no, Judge Adam, no! Why, who would give

The parties such ambiguous instruction.

MARTHA. If she can tell me to my very face,

Shameless like that, and dissolute, the slut,

That anyone but Ruprecht was the one,

For all I care she can-I won't say what.

But I, I do assure you now, Your Honor,

And though I cannot guarantee she swore,

She said it yesterday, and that I'll swear,

As I affirm by Joseph and by Mary. 
ADAM. Now furthermore the maiden wants-

WALTER.

Your Honor!

ADAM. Your Grace? - What is it? -Don't you, Evie darling?

MARTHA. Now, out with it! Did you not tell me so?

Didn't you tell me, yesterday, this thing?

Eve. Well, who denies I said it-

ADAM.

There you are.

RUPRECHT. The harlot!

ADAM.

Write that down.

VEIT.

Fie, shame on you.

WALTER. Of your behavior here in court, Judge Adam,

820

I don't know what to think. If you yourself

Had smashed Dame Martha's jug, you hardly could

More zealously attempt to shift suspicion

From you to this young man, than you are doing.-

You're putting no more in the record, Clerk,

Than just this girl's admission, I should hope,

Of yesterday's confession, not the facts.

-Is it the maiden's turn to testify?

ADAM. My soul, if it is not her proper turn,

In such affairs a man can err, Your Grace.

830

Whom else should I have questioned? The accused?

Upon my word, I'm glad to be instructed.

WALTER. How nonchalant! - Yes, question the accused.

Ask and be done with it, yes, ask, I beg:

This is the last case you will ever try.

AdAM. The last one! What! 0 surely! The accused!

For where indeed, old Judge, where were your thoughts?

0 curses on that chicken with the pip!

Had it but died in India of the plague!

That noodle dumpling sticks here in my crop.

WALTER. What sticks? What sort of dumpling-? 
ADAM.

Noodle dumpling,

That, by your leave, I am to give the hen.

If she'll refuse to swallow down the pill,

My soul, I don't know how the thing will end.

WALTER. In the hangman's name, I tell you, do your duty! 845

ADAM. Accused, step forward.

RUPRECHT.

Here I am, Your Honor.

Ruprecht, the son of Veit, the Huysum cotter.

ADAM. Well, did you hear the charge before this court

Dame Martha has preferred just now against you?

RUPRECHT. Indeed, Your Honor, yes.

850

ADAM.

And will you dare

To bring up anything to contradict her?

Will you confess, or will you be so bold,

So Godforsaken, and deny the charge?

RUPRECHT. You ask what I can say in contradiction,

Your Honor? Well! I say, with your permission,

855

That she has uttered not a word of truth.

ADAM. You do? And you expect to prove it?

RUPRECHT. $O$ yes.

ADAM. Dame Martha, you, my worthy friend,

Be of good cheer. All things will come to light.

Walter. What has Dame Martha, Judge, to do with you? 860

ADAM. What she-?My Lord! Shall I as Christian-?

WALTER.

Tell

Whatever you can say in your defense.-

Clerk, do you know how to conduct this case?

ADAM. Oh, stuff !

LIGHT.

Do I-why, if Your Grace would please-

ADAM. Why stare like that? What have you to bring up? 865 Doesn't this donkey stand there like an ox?

What have you to bring up? 
WALTER. You, yes, you're now to tell us just what happened.

RUPRECHT. My soul, if they would let me say my say.

WALTER. In truth, Judge Adam, it's not to be borne.

870

RUPRECHT. It may have been at ten o'clock last night-

And just this night of January warm

As May-that I said to my father, 'Dad,

I think I'll go and talk with Eve a bit.'

For you must know, I would have married her;

875

A sturdy wench she is, at harvest time

I watched and saw how quick and sure her hand,

And how the hay flew like a mousing cat.

So I said, 'Will you?' And she answered, "Oh!

How you do cackle." Later she said, "Yes."

880

ADAM. Stick to the question, you. Cackle! What stuff!

I asked her, 'Will you?' And she answered, "Yes."

RUPRECHT. She did in truth.

WALTER.

Get on, get on!

RUPRECHT.

And so-

I said, 'You hear me, Father? Let me go.

We'll have a little chat outside the window.'

885

Says he, "All right; you'll stay outside?" says he.

'Upon my soul,' says I, 'I swear I will.'

"Then run," says he, "be back here at eleven."

ADAM. Says he, says you, and cackle, and no end.

How soon will you have said your say?

890

RUPRECHT.

So then

I says, 'A bargain,' and I put my cap on

And go; and want to cross the bridge, and must

Go through the village, since the brook's in flood.

Well now, by thunder, thinks I, Ruprecht, damn!

By now the gate to Martha's yard is shut:

For only up to ten Eve leaves it open;

If I'm not there by ten, then I'm not coming.

ADAM. Disreputable goings on.

ẄALTER.

And then? 
RUPRECHT. And then-as I come nearer through the limes At Martha's, where the rows are closely arched $\quad 900$ And gloomy as the minster is at Utrecht, I hear the creaking of the garden gate. Well, well! Then Eve is out there still, says I, And gaily send my eyes to search the place From where my ears had brought me news of her- 905 And censure them, when they come back to me, As blind, and on the spot I send them out A second time, to take a better look, And rail at them as villainous defamers, As vile inciters, infamous slanderers, And send them out a third time, and I think, Since they have done their duty well, they must In anger pull themselves out of my head, And ask for transfer to another service: It's Eve herself, I know her by her bodice, And some one else is with her.

ADAM. What? Some one else? And who, you smarty, you?

RUPRECHT. Why? Well, my soul, you have me there-

ADAM. You see!

And till he's caught, I guess, he won't be hanged.

WALTER. Go on! Complete your tale! Judge, let him be! 920 Why do you interrupt so much, Judge Adam?

RUPRECHT. I cannot swear it by the Sacrament, It was pitch dark, and then all cats are gray.

But you must know this, that the cobbler Lebrecht, Whom lately they declared unfit for service,

Has long since been upon young Eva's trail.

Last fall I said to her, 'Now Listen, Eve,

That scamp's too near your house, and I don't like it;

Tell him that you're no banquet for his palate,

Or else, my soul, I'll throw him out the door.'

She says, "Don't pester me," and tells him something That's neither here nor there, not fish nor flesh:

So I go in and throw the rascal out. ADAM. Ah? Lebrecht is his name? 
ADAM.

That is a name. We'll get the straight of this.

-You've got that in your record, Mr. Clerk?

LIGHT. 0 yes, and all the other things, Your Honor.

ADAM. Speak further, Ruprecht, now, my son.

RUPRECHT.

But now,

Since I had met the pair here at eleven,

-I used to leave at ten-my eyes were opened.

Thinks I, hold on there, Ruprecht, you've got time,

As yet you haven't grown a set of antlers:-

But you must carefully inspect your forehead,

To see if horny spots are sprouting there.

I squeeze in gently through the garden gate

And hide myself behind a bush of yew:

I hear a whisperng there, a dalliance,

A pulling and a tugging back and forth, My soul, I thought desire would-

EVE.

How shamefully you acted!

Villain you!

MARTHA.

Why, you rascal!

I'll show you yet, when once we are alone,

My teeth! Just wait! You don't know yet just where

I have my claws! But you shall learn!

RUPRECHT. A quarter hour this thing went on; thinks I,

What's going on, this is no wedding day?

Before the thought was finished in my mind,

Whish! they were in the house, without a priest.

EvE. Now, Mother, let things happen as they will-

ADAM. Be silent now, I counsel you, or thunder

Will strike you down, you uninvited babbler!

Wait till I call you up to testify.

WALTER. Peculiar, by the Lord!

RUPRECHT.

It rises like a rush of blood. Air!

And now it rises,

And bursts a button on my vest: Air now!

I open up my vest: Air now, I say!

And go, and push, and kick, and thunder, 
Because I find her chamber door is bolted, And brace myself. and knock the door right in.

ADAM. Young devil, you!

RUPRECHT. Just as it crashes in,

The jug there tumbles from the mantle shelf, 970

And whish! a man goes jumping through the window:

I see his coat tails flying as he leaps.

ADAM. And that was Lebrecht?

RUPRECHT.

Why, who else, Your Honor?

There stands the girl, I push her to one side,

Rush to the window, and I find the fellow 975

Impeded by the posts that hold the trellis,

Where vines go climbing upward to the roof.

And as I hold the door latch in my hand,

From pounding in the door, I land him one,

Pounds heavy, with the steel across his pate:

For that, Your Honor, still was in my reach.

ADAM. It was a latch?

RUPRECHT.

ADAM.

RUPRECHT.
What?

$$
\text { Was it-? }
$$

Yes, the door latch.

ADAM. That's why.

LIGHT.

Perhaps you thought it was a sword?

ADAM. A sword? I thought-how so?

RUPRECHT.

LIGHT.
A sword!

Oh well,

One's ears can play one false. I think a latch

ADAM. I think-!

LIGHT.

Upon my word! The shaft, Your Honor?

ADAM. The shaft!

RUPRECHT. The shaft! But that was not the case.

You see, it was the latch's other end. 
ADAM. Oh ho, the latch's other end it was!

LIGHT. Oh! Oh!

RUPRECHT. But on the handle was a lump

Of lead, quite like a sword hilt, I must say.

ADAM. Yes, like a sword hilt.

LIGHT. Good. Just like a hilt.

Some nasty kind of weapon, certainly,

It must have been. So much I knew.

995

WALTER. Stick to the point, good sirs, I beg! The point!

ADAM. It's only foolery, Mr. Clerk!-Proceed, you!

RUPRECHT. The fellow falls, and I'm about to turn,

When in the dark I see him struggle up.

Thinks I, what, still alive? and mount the window 1000

To get down there and stop the rascal short:

But now, good sirs, as I am crouched to leap,

A mighty handful of coarse sand comes flying

Like hail and strikes me squarely in the eyes-

And man and night and world and window sill

1005

On which I stand, God knows, before I know it,

All that is jumbled in one blinding sack.

ADAm. Curses! Well, well! Who did that?

RUPRECHT.

Who? Why, Lebrecht.

ADAM. The scoundrel!

RUPRECHT. Yes, my faith! If it was he.

ADAM. Who else!

RUPRECHT.

As if a rain of hail had cast

Me down ten fathoms from a mountain slope,

Just so I tumbled down into the room:

I thought I'd certainly break through the floor.

I didn't break my neck, that's true, nor yet

My back or hips or other bones, but still

I could no longer lay hands on the fellow.

So up I sat and wiped sand from my eyes.

She comes, and "O, dear God!" she cries, and "Ruprecht! 
What ails you now?" My soul, I raised my foot, Good thing I couldn't see where I was kicking.

ADAM. That's what the gravel did?

RUPRECHT.

The gravel, yes.

ADAM. By damn! A hit!

RUPRECHT. When I got up again,

I thought I'd not profane these fists of mine.

I railed at her and called her filthy slut,

And thought that that was good enough for her. 1025

But then I cried and couldn't say a word.

For when Dame Martha came into the room

And raised the lamp, so that I saw the girl

All trembling there before me, pitiful,

She who had always looked so frank and free,

1030

I told myself: blindness is not so bad.

And I'd have gladly given up my eyes

As marbles, let some youngster play with them.

Eve. He is not worth, the villain-

ADAM. Hold your tongue!

RUPRECHT. The rest you know yourself.

ADAM.

How so, the rest?

RUPRECHT. Oh well, Dame Martha came along and fumed,

And neighbor Ralf came in, and neighbor Hinz,

And cousin Sue and cousin Lisbeth came,

And men and maids and dogs and cats came in:

It was a riot, and Dame Martha asked

The maiden here who was it broke the jug,

And she, she said, you know, that it was me.

My soul, good sirs, she's not so wrong at that.

The jug she bore to water I did break,

And now the cobbler's head has got a hole.-

ADAM. Dame Martha! What is your reply to this? Speak up.

MARTHA. What I would answer in reply?

I'd say this speech comes like a thieving marten 
And throttles truth as if 'twas a cackling hen.

All friends of the right should take a club in hand 1050 And put to death this monster of the night.

ADAM. Then you must put your statement to the proof.

MARTHA. Quite willingly. Here is my witness. -Speak!

ADAM. Your daughter? No, Dame Martha.

WALTER.

No? Why not?

ADAM. As witness here, Your Honor? Don't the law code 1055 Say verbally in section quarto, quinto?

That when a jug or such-how should I know?

- Has been by youthful rascals smashed to bits,

Then daughters bear no witness for their mothers?

WALTER. Within your head lies knowledge close by error, 1060

Together kneaded as a dough of sorts;

With every slice you give me some of each.

The maiden does not witness, she declares;

If, and for whom, she will and can bear witness,

That will appear when she makes declaration.

1065

ADAM. Ah ha, declare. Good. That's in section sexto.

But what she says is not believed.

WALTER. Come forward, child.

ADAM. $\quad H e y$, Lisa! - (To Walter.) By your leave! My tongue is drying up-Hey, Margaret!

\section{SCENE EIGHT}

(A Maidservant enters.)

ADAM. A glass of water, you!-

MAID.

At once!

ADAM.

Can I-?

WALTER. No thanks.

ADAM.

Moselle? Or Rhine wine? What you will.

(Walter bows; the Maid brings water and withdraws.) 


\section{SCENE NINE}

ADAM. If I may make so bold to speak, Your Grace, This case is suited well for settlement.

WALTER. For settlement? That is not clear to me.

People of sense can find a settlement;

But how you hope to settle matters now, Before the case has even been untangled, I must confess I'd like to hear you tell. How do you think to manage, tell me that?

Have you a judgment ready made?

ADAM.

My soul!

If I, because the law forsakes me now,

Must take philosophy to be my aid,

Then it was-Leberecht-

WALTER.

No, who?

ADAM.

Or Ruprecht-

WALTER. Who?

ADAM.

Or 'twas Lebrecht, yes, that broke the jug.

WALTER. Who was it then? Was it Lebrecht or Ruprecht? 1085

I see your judgment blindly grope about,

Just like five fingers in a sack of peas.

ADAM. I say!

WALTER. Be still, I beg you.

ADAM.

As you will!

Upon my honor, it would please me well,

If both of them had been the guilty ones.

WALTER. Ask her, and you'll find out.

ADAM.

Most willingly.

But if you find it out, then I'm a scoundrel.

-(To Light.) You have the minute-book in readiness?

LIGHT. Quite.

ADAM. Good. 
LIGHT.

I'm starting now a special sheet

Eager to see what shall be written on it.

ADAM. A special sheet? That's good.

WALTER.

Speak there, my child.

ADAM. Speak, Evie, mark you, speak now, maiden Eva!

Give God, my darling, mark you, give, my soul,

To God and to the world a bit of truth.

Think that you're at the judgment seat of God,

1100

And that you must not with denials vex

Your judge, and must not babble silly words

Beside the point. 0 pshaw! You have good sense.

A judge, you know, will always be a judge, And one needs him today, and one tomorrow.

Say then that it was Lebrecht: very good;

Or say that it was Ruprecht: also good!

Say this or that, and I'm no honest man,

If things don't then turn out just as you'd like.

But if you try to babble of another,

A third perhaps, and mention foolish names:

Then, child, look out, that's all I have to say.

In Huysum, what the deuce, none will believe you, And no one, Evie, in the Netherlands;

You know that whitewashed walls don't testify,

And he will manage to defend himself:

And then your Ruprecht goes straight to the devil.

WALTER. I wish you would desist from all this talk.

Mere chatter, neither fish nor good red herring.

ADAM. Your Honor does not follow me?

1120

WALTER.

Get on!

Too long you have been speaking on this bench.

ADAM. 'Pon honor! I'm no learned man, Your Grace.

If I'm obscure to you who come from Utrecht,

Among this folk perhaps it's not the same:

The maiden knows, I'll venture, what I want.

MARTHA. What is all this? Come, out with it, and speak!

EvE. O dearest Mother! 
MARTHA. You-! I'm warning you!

RUPRECHT. My soul, it's hard, Dame Martha, to speak out, When conscience holds a person by the throat.

ADAM. Keep still now, smarty, hold your tongue.

1130 MARTHA.

Who was it?

Eve. O Jesus!

MARTHA. See that vile and common booby!

0 Jesur! Just as if she was a whore.

Was it Lord Jesus?

ADAM. Senseless talk, Dame Martha!

What sort of-? Leave the girl in peace there, can't you?

Scaring the child so-whore-you mutton-nead!

1135

That gets us nowhere. She'll know what to say.

RUPRECHT. O, sure she will.

ADAM.

You lout here, shut your mouth.

RUPRECHT. The cobbler's name will pop up in her mind.

ADAM. You Satan! Call the bailiff! Hey! Hanfriede!

RUPRECHT. All right! I'll say no more, Judge, let it go. 1140

She'll do your will and hit upon my name.

MARTHA. Now listen, make no scandal here, I say.

For I have come to nine-and-forty years

In honor, and I'd like to make it fifty.

My birthday is the third of February;

1145

Today's the first. Now hurry up. Who was it?

ADAM. I call that good! Good work, Dame Martha Rull!

MARTHA. Her father said before he died, "Now Martha,

You get the girl a proper man as husband;

If she should turn out dissolute and loose,

Then give the grave digger an extra penny

And have him lay me on my back again:

My soul, I'd turn right over in my grave."

ADAM. That too is not so bad. 
MARTHA. If yoú would honor

Father and mother now, my Evie, as the fourth 1155

Commandment bids, then say: "into my room

I let the cobbler come, or someone else,"

You hear? "But it was not my promised man."

RUPRECHT. I grieve for her. Let the jug be, I beg you;

I'll take it into Utrecht. Such a jug-

1160

I only wish 'twas really me that smashed it.

EvE. Ignoble words from you! 0 fie, for shame

That you don't say: all right, I broke the jug!

Fie, Ruprecht, fie, 0 shame on you, that you

Cannot have faith in me and what I did.

Didn't I give my hand and answer Yes,

That time you asked me, "Eva, will you have me?"

Do you suppose you're not the cobbler's match?

And even if you'd seen me, through the keyhole,

With Leberecht, and drinking from the jug.

You should have thought, my Eve is good and true,

And all will be explained to do her credit,

If not in this life, then beyond the grave.

And when we rise again there'll still be time.

RUPRECHT. My soul, that takes too long for me, my Eve. 1175

What I can put my hands on, that I'll trust.

EvE. Suppose for once it had been Leberecht,

Then why-for I will die eternal death

If I'd not told you, for yourself alone;

But why before the neighbors, men and maids-

1180

Suppose I had some reason to conceal it,

Then tell me, Ruprecht, speak, why shouldn't I,

Relying on your faith, say it was you?

Why shouldn't I do that? Why not, I say?

RUPRECHT. Well, say it then, in the devil's name, I'm willing,

If that's your way to dodge the pillory.

Eve. O you atrocious man, ungrateful you!

Well worth my dodging pillory! Well worth,

That with a single word I clear my name

And throw you into everlasting ruin. 
WALTER. Well-? And this single word-? Don't waste our time.

It was not Ruprecht then?

Eve. No, please Your Honor, since he wants it so,

'Twas only for his sake I hid the truth:

This earthen pitcher Ruprecht did not break,

1195

If he denies it, you may take his word.

MARTHA. What, Eve! Not Ruprecht?

EvE.

No, dear Mother, no!

And if I said it yesterday, I lied.

MARTHA. My girl, I'll break your every bone! (She sets down the jug.)

Eve. Do as you will.

1200

WALTER (threatening). Dame Martha!

ADAM.

Hey! The bailiff !-

Take her and throw her out, the curséd hag!

Why did it have to be just none but Ruprecht?

Was it you that held the light for him, I wonder?

The maiden, I should say, must know the facts:

I am a rogue if it wasn't Leberecht.

1205

MARTHA. Now, was it he perhaps? Speak, was it Lebrecht?

ADAM. Speak, Eve, was it not Leberecht, my darling?

Eve. You shameless man! You miserable sneak!

How can you say that Leberecht-

WALTER.

Young woman!

What impudence! Is that the due respect

That you should pay the judge upon the bench?

Eve. Good land! This judge you mean! He well deserves

To stand as sinner here bofore the court-

- He who could better tell who broke the jug!

(Turning to Judge Adam)

Didn't you send Lebrecht to town yourself

1215

Just yesterday, to take to the commission

The list of names, before they choose recruits?

How can you say that Lebrecht broke the jug,

When you know well that he was gone to Utrecht? 
ADAM. Well then, who else? If he did not, deuce take it- 1220 Not Ruprecht and not Lebrecht-Well, what is it?

RupRECHT. My soul, Judge Adam, let me tell you this,

The girl is not so wrong in what she says,

For I myself met Lebrecht yesterday

As he was bound for Utrecht, eight it was,

1225

And if he got no ride upon a cart,

Bowlegged as he is, that fellow sure

Had not yet hobbled back by ten at night.

It may quite well have been another man.

ADAM. What's that? Bowlegged! Fathead! Why, that chap 1230

Can shake a leg as well as any man.

Let me not be two-legged here myself,

If any shepherd dog of common size

Won't have to trot to keep abreast of him.

WALTER. Tell us what happened.

1235

ADAM.

By Your Honor's leave!

For such a task the girl would hardly serve.

WALTER. Not serve? Not serve me? And why not, I ask?

ADAM. A stupid child. You see that. Good, but stupid.

Quite young yet, scarce confirmed; she's still ashamed

To see a beard a mile away. Such girls

1240

Will let themselves be used at night, but then

By day deny it to their judge's face.

WALTER. You're very lenient, Judge, I'm bound to say,

And very mild in all that touches her.

ADAM. To tell the honest truth to you, Judge Walter,

1245

Her father always was a friend of mine.

And if Your Grace will be so kind today,

Then we will do no more than just our duty

And let his daughter go.

WALTER. I feel a great desire in me, Your Honor,

1250

To probe this matter to the very bottom.-

Be bold, my child; tell us who broke the jug.

You face here no one, at the present moment,

Who could not well forgive an erring step. 
EvE. Most worthy Lord, and dear and gracious sir,

Do not insist that I should tell you all,

And don't take it amiss that I refuse.

It's Heaven's wondrous disposition, sir,

Which seals my lips in this uncommon case.

That Ruprecht didn't touch the jug I will

1260

Affirm, and with an oath, if you demand it,

And swear to it before the holy altar.

But that which happened yesterday is mine,

With every detail that belongs to it,

And Mother cannot claim the cloth entire

1265

Because one thread, that may be hers to claim,

Just happens to go through the tangled web.

I cannot here report who broke the jug,

For secrets that are not my property

I'd have to bare, quite foreign to the jug.

1270

Some time or other I'll confide in her,

But this tribunal here is not the place

Where she may claim the right to ask me this.

ADAM. No, not by rights. Upon my honor, no.

The girl knows where our bridles may be found.

1275

If she will take her oath before this court,

The mother's charge is null and void:

Against this there is nothing to be said.

WALTER. What's your reply, Dame Martha, to this statement?

MARTHA. If I do not at once say something weighty, 1280

Your Grace, then do believe, I beg of you,

It's that a stroke has lamed my tongue for me.

It has been known to happen that a man,

To elevate his name before the world,

Perjured himself before a court; but that

1285

A lying oath could be performed upon

The altar, so the pillory might be won,

That is the thing the world has never seen.

Had any other man than Ruprecht, sir,

Been proven to have sneaked into her room,

If that was even possible, Your Grace,

You understand me-I'd stay here no longer.

I'd put a chair, as first piece of her dowry, 
Before her door, and say: begone, my child, The world is wide, you'll pay no rental there,

And part of your inheritance is hair

On which, when time is ripe, to hang yourself.

WALter. Be calm, be calm, Dame Martha.

MARTHA.

Inasmuch

As I can furnish other sorts of proof,

Than through her who refuses me that service,

1300

And am convinced and certain that 'twas he

And no one else who broke the jug for me,

This eagerness to make a curt denial

Suggests a base conjecture to my mind.

For last night's doing hides, I think, another

1305

Offence than just the smashing of the jug.

For I must tell you, honored sir, that Ruprecht

Has been conscripted, and it won't be long

Till he swears fealty to the flag at Utrecht.

The younger lads, I hear, are now deserting.

Suppose that Ruprecht went to Eve last night:

"What think you, Evie? Come. The world is large.

To chests and drawprs, you know, you have the keys-"

And she, suppose that she had balked a bit:

Why then by accident, when I disturbed them-

Revenge on his part, love at work on hers-

The whole thing could have happened as it did.

RUPRECHT. You carrion! To say such things as that!

To chests and drawers-

WALTER.

Stop!

Eve.

What, he desert!

WALTER. The point, the point! We're speaking of the jug.-1320 Bring on the proof that it was Ruprecht broke it.

MARTHA. All right, Your Grace. Then first I now will prove

That Ruprecht broke the jug for me,

And then I'll go to searching in my house.-

Look here, a tongue to testify for me

I will produce for every word he said,

And would have stood them up at once in rows 
If I'd so much as dreamed that this my girl Would not employ her tongue in my behalf. But if you'll call Dame Bridget into court,

That's Ruprecht's aunt, then she will serve my needs,

Since she will call the central point in question.

For she, at half past ten there in the garden-

Mark that, before the pitcher had been broken-

She came upon him crossing words with Eve;

1335

And how the fable he has put to rights

Is split in two thereby from head to foot

By this one speaking tongue, you worthy judges:

I leave that inference to your own wits.

RUPRECHT. Who saw me-?

1340

VEIT.

Sister Briggy?

RUPRECHT.

Me with Eve? Outside?

MARTHA. Saw him with Eve, outside, at half past ten,

Before he came, as he pretends, to break

The room door in with violence at eleven;

Exchanging words, now petting her, now coaxing,

As if he'd try to talk her into something.

1345

ADAM (aside). My Lord. The devil's on my side.

WALTER. Bring in this woman.

RUPRECHT.

Gentlemen, I beg you:

No word of that is true; impossible.

ADAM. O wait, you villain! - Hey! Hanfriede! Bailiff !-

For when one flees, then jugs are often broken- 1350

You, Clerk, please go and bring Dame Bridget here!

VEIT. Listen, you curséd scamp, what's this you're doing?

I'll break your bones in two.

RUPRECHT.

You will, and why?

VEIT. Why did you hide the fact that with the girl

You flirted in the yard at half past ten?

1355

Why did you hide that fact?

RUPRECHT.

Why did I hide it? 
God's thunder, Dad! Because it isn't true! If that's Aunt Bridget's testimony, hang me. And her too by the legs, for all I care.

VEIT. But if she says it, boy-look out for me!

You and this tidy maiden Eva there,

Whatever tale you tell this court, you're tarred

Both with the selfsame stick. For there is still

Some shameful secret left, of which the girl

Has knowledge, but conceals it just to spare you.

RUPRECHT. A secret? Which?

VEIT.

Why did you pack your things?

Come now, why were you packing up last night?

RUPRECHT. My things?

VEIT.

Your trousers, yes, and coats, and linen;

To make a bundle which a traveler might

Throw on his back.

1370

RUPRECHT. Because I'm going to Utrecht!

I have to join my regiment! By thunder-!

You think that I-?

VEIT.

To Utrecht? Oh, to Utrecht!

You were in haste, I think, to get to Utrecht!

Two days ago you didn't even know

If il would be the fifth day or the sixth.

1375

WALTER. Father, have you some facts to tell the court?

VEIT. - Your Honor, I'd as yet make no assertion.

I was at home when yonder jug got broken,

Nor have I of another undertaking

Sure evidence, if I must speak the truth,

1380

And, if I balance every circumstance,

Nothing to throw suspicion on my son.

I came here quite convinced he had no blame,

And my intent, when once this trial's done,

Was to annul his marital engagement,

1385

And to get back for him the silver necklace 
And little medal he had given the girl

Last autumn, when the couple plighted troth.

Now if a flight is mentioned, and attempts

To work some treason on this aging head,

That is as new to me, sir, as to you:

In that case, may the devil break his neck.

WALter. Please have Dame Bridget brought to court, Judge Adam.

ADAM. - Will not Your Honor find yourself worn out

With such a case? It's getting long drawn out.

1395

You know you still have my accounts to see,

And then the records too-What is the time?

Light. The half just struck.

ADAM.

Past ten?

LIGHT.

No, past eleven.

WALTER. All right.

ADAM. I think the time is mad, or you. (He looks at the clock.)

I am no honest man-Well, what's your will?

WALTER. I'm minded-

ADAM.

To conclude the hearing? Right-!

WALTER. Your pardon! I am minded to continue.

ADAM. You're minded-Right, as well. Or I'd engage,

Upon my word, tomorrow sharp at nine

To end the case to your complete contentment.

1405

WALTER. You know my wishes now.

ADAM.

As you command.

Clerk Light, send out the bailiffs; bid them straight

To bring Dame Bridget here before the court.

WALTER. I beg you, Clerk-to save my precious timeYourself to see this order's carried out. (Exit Light.) 


\section{SCENE TEN}

(The same without Clerk Light. Later: Maidservants.)

ADAM (rising). Meanwhile I think one might, if that's your pleasure,

Get up and stretch one's legs a bit-?

WALTER.

Hm! Yes.

As I was going to say-

ADAM.

Will you permit

The parties here, until Dame Bridget comes-?

WALTER. What's that? The parties?

1415

ADAM.

Yes, outside, if you-

WALter (aside). 0 damn! (Aloud.) Judge Adam, may I then suggest?

Give me a glass of wine to pass the time.

ADAM. With all my heart I will. Hey! Margaret!

You make me very happy, sir.-You, Greta!

MAID (enters). Here.

ADAM.

What's your choice?-You may go out, you people.

French?-Out there in the anteroom.-Or Rhine wine?

WALTER. Wine from our Rhine.

ADAM.

Good. -Till I call you. March!

W ALTER. Where to?

ADAM.

Go, get the sealed wine, Margaret.-

What? To the anteroom.-Here.-Take the key.

WALTER. Hm! Wait.

Adam. Go! March, I say! -Go, Margaret!

Bring butter, freshly molded, cheese from Limburg, And some of that fat smoked Pomeranian goose.

WALTER. Wait! Just a moment! Do not make so much Ado here, Judge, I beg of you. 
ADAM. You get

The devil out of here! (To Maid.) Do as I said.

WALTER. You're sending out the parties, Judge?

ADAM.

Your Grace?

WALTER. I asked-

ADAM.

They will withdraw, if you permit.

But only till Dame Bridget comes.

Or is your will perhaps-?

WALTER.

Hm! As you like.

But yet I wonder if it's worth the trouble.

1435

Will it, do you consider, take so long

To find her in the village?

ADAM.

It's wood day,

Your Honor, and the women hereabouts

Are mostly in the woods, to gather fagots.

It might well be-

1440

RUPRECHT.

No, Auntie is at home.

WALTER. At home. So let it go.

RUPRECHT.

She'll be right here.

WALTER. She'll be right here, he says. Bring on the wine.

ADAM (aside). 0 hell!

WALTER.

Go then. But serve no food, I beg,

Except a slice of bread with salt, no butter.

ADAM. (aside). Give me two seconds with the girl alone-1445

(Aloud.) What, bread with salt! No butter! Nonsense.

WALTER.

Really.

ADAM. At least a piece of Limburg cheese. -For cheese

Prepares the tongue so it can taste the wine.

WALTER. Agreed. A piece of cheese, but nothing more.

ADAM. Then go. And lay a cloth of damask, white.

Quite plain, all this, but good. (Exit Maid.) That's the advantage 
We bachelors do have, though much defamed, That what the others, scant, and sorrowful, Must daily share with wife and hungry children, We can enjoy with friends in proper season 1455

To heart's content.

WALTER.

As I was going to say-

How did you ever get that wound, Your Honor?

A nasty hole, my word, there in your head!

ADAM. -I fell.

WALTER.

You fell. Hm! Well. When? Just last night?

ADAM. No, pardon me, this morning, at five-thirty, 1460 And just as I was getting out of bed.

WALTER. And over what?

ADAM. Why, please Your Grace,

To tell the truth, I fell over myself.

I plunged head first against the stove, you see, And till this hour I don't know why I did.

WALTER. Fell backwards?

ADAM.

How? Fell backwards-

WALTER. Or fell forwards?

You have two wounds, one front and one in back.

ADAM. Backwards and forwards. - Margareta!

(The two Maids come in with wine, etc. They set the table and go out again.)

WALTER.

What?

ADAM. First so, then so. First on the iron edge,

Which knocked my forehead in, then right away

1470

I backwards fell again upon the ground

And thus I smashed my cranium in the rear. ( $\mathrm{He}$ pours wine.)

Will you be served?

WALTER (takes the glass). Now if you had a wife,

Then I could credit most peculiar things,

Your Honor. 
ADAM. How is that?

WALTER. Yes, by my faith,

I see you scraped and scratched on every side.

ADAM (laughs). No, God be praised! Those were not women's nails.

WALTER. No doubt. That too's a bachelor's advantage.

ADAM (laughing on). Branches for silkworms, set up there to dry

Beside the stove, just where I had to fall.-

1480

Here's to your health! (They drink.)

WALTER. And just today

You had to lose your wig so strangely, too.

That would at least have covered up your wounds.

ADAM. You're right. It seems misfortune is a twin.-

Here-of this fat cheese now-can I?

1485

WALTER.

A morsel.

From Limburg?

ADAM. $\quad$ Straight from Limburg here, Your Grace.

WALTER. - But how the devil, tell me, could that happen?

ADAM. What?

WALTER. Why, that you could wholly lose your wig.

ADAM. I'll tell you how. Last night I sat and read

A case at law, and had mislaid my specs,

$149 \mathrm{C}$

And so I got so deep into the case

That to the lighted candle getting close

My wig took fire, and I, at first I thought

That flames from Heaven had struck my sinful head

And seized the wig to cast it far from me;

1495

Before I'd loosed the ribbons at my neck

'Twas burning like to Sodom and Gomorrha.

I barely saved the three hairs I have left.

WALTER. Too bad! You say your other one's in town?

ADAM. Yes, at the wig shop. -But let's get to work. 1500

WALTER. Wait, not so fast, I beg of you, Judge Adam. 
AdAM. 0 pshaw! Time rushes on. A small glass, here. (He pours wine.)

WALTER. Now Lebrecht-if that fellow spoke the truthHe must have had a nasty tumble too.

ADAM. 'Pon honor, yes. (Drinks.)

1505

WALTER.

So if this case in court

Is left unravelled, as I fear 'twill be,

You can detect the doer by his wounds

Here in this town, whenever he appears. (Drinks.)

Niersteiner?

ADAM.

What?

WALTER.

Or first-rate Oppenheimer?

ADAM. Nierstein. Look, look! You know your wines.

1510

From Nierstein, sir, as if I'd gone to get it.

WALTER. I tried it at the press, three years ago. (Adam pours wine again.)

-How high, now, is your window?-You! Dame Martha!

MaRTHA. My window?

WALTER.

Yes, the window of that room

In which your daughter sleeps.

1515

MaRTHA.

The room itself

Is just one story high, above the cellar,

The window's but nine feet above the ground;

And yet the whole arrangement, well devised,

Is very awkward, sir, for leaping out.

For two feet from the wall there is a vine

1520

Which sends its knotty branches twining up

And through a trellis all along the wall;

The window frame itself is lined with vines.

A sturdy boar, though armed with heavy tusks,

Would have no easy task to break through that. 1525

ADAM. There was no boar caught there. (Fills his glass.)

WALTER.

You think so?

ADAM.

Pshaw! (Drinkes.) 
WALTER (to Ruprecht). How did you hit the sinner? On the head?

ADAM. Here.

WALTER. Stop.

ADAM. Give here.

WALTER. It's still half full.

ADAM. I'll fill it.

WALTER. You heard me.

ADAM. $\quad$ Make the number right.

WALTER.

I beg you.

ADAM. Nonsense! We heed Pythagorean rules. (Fills his glass.)

WALTER (to Ruprecht). How often did you hit the sinner's head?

ADAM. One is the Master; Two is chaos dark;

Three is the world. Three glasses, that's my style.

For with the third glass you have suns to drink,

And with the rest you have the firmaments.

1535

WALTER. How many times you hit the sinner's head?

You, Ruprecht, I am asking!

ADAM.

Will you speak?

How oft you hit the scapegoat? Out with it!

God's lightning, does he know himself if he- -

Remember?

1540

RUPRECHT. With the door latch?

ADAM. How should I know?

WALTER. Yes, when you struck him through the window.

RUPRECHT. Two times, good sirs.

ADAM.

The rascal! That he knows! (Drinks.)

WaLter. Two times! With two such mighty blows you could Have killed him, you know that-? 


\section{RUPRECHT. $\quad 0$, if I had,}

I'd have him now. And that would suit me well.

If he lay dead before me, I could say,

That's him, good sirs, I haven't lied to you.

ADAM. Yes, dead! I warrant you. But now-(He pours wine.)

WALTER. You couldn't recognize him in the dark?

RUPRECHT. Not in the least, Your Grace. What chance of that?

ADAM. Why, if you'd opened your eyes! -Clink glasses now!

RUPRECHT. What, open my eyes! I had them opened wide.

That Satan filled them up with sand.

ADAM (in his beard). Yes, sand!

Those staring eyes, why open them so wide?

-Here. To our best beloved, Your Grace! Your glass! 1555

WALTER. - I toast what's right and good and true, Judge Adam!

AdAm. Well then, let's finish this, if you're agreed. (Pours wine.)

WALTER. You sometimes visit at Dame Martha's house,

No doubt, Judge Adam. Tell me, if you please,

Who else but Ruprecht goes there in and out.

1560

ADAM. I'm not so often there, sir, by your leave.

I cannot tell you who frequents the place.

WALTER. How? Don't you now and then go there to see

The widow of your late lamented friend?

ADAM. No, no, indeed, I'm seldom there.

WALTER.

Dame Martha!

Have you spoiled your friendship with Judge Adam?

He says he doesn't often call on you.

MARTHA. Hm! Spoiled, Your Honor? Not exactly that.

I think he still will call himself my friend.

But that I see him often in my house,

Of that, I'd say, I can't exactly boast.

It's nine weeks now since he was last inside,

And then 'twas just as he was passing by. 
WALTER. How's that?

MARTHA.

WALTER.

MARTHA.

What then?

Nine weeks ago-?

Yes, nine,

On Thursday 'twill be ten. He begged same seeds 1575

of me, carnations and some primulas.

WALTER. And-Sundays-when he goes out to his farm-?

Martha. Yes, then-he'll peep a bit into my window,

And say good day to me and to my daughier;

But after that continues on his way.

WALTER (aside). Hm! Should I have misjudged the man(Drinks.) I thought,

Since you from time to time employ the girl

To help out in your house, in gratitude

You'd call upon her mother now and then.

ADAM. How so, Your Grace?

1585

WALTER.

How so? You said yourself,

The maiden here had nursed your chicks to health,

When they fell sick for you. And didn't she

Today give you advice in such a case?

Martha. Yes, to be sure, Your Honor, that she does.

Two days ago he sent a guinea hen 1590

To her, so sick that it was like to die.

Last year she cured one of the pip for him,

And this one too she'll save by cramming it:

But he has never come to show his thanks.

WALTER (confused). - Pour out some wine, Judge Adam, if you will.

Fill up my glass. We'll take another draft.

ADAM. Your service, sir. You make me happy. Here. (He pours wine.)

WALTER. Here's to your health. - (To Martha.) Judge Adam, I should think,

Will soon or late appear. 
MARTHA. You would? I doubt it.

If I had Nierstein wine, such as you drink, 1600

And as my late lamented husband had,

The castellan, at times, down in the cellar,

To serve my cousin, 'twould be different:

But now, poor widow that I am, I've nothing

Within my house to lure him into it.

WALTER. So much the better.

1605

\section{SCENE ELEVEN}

(Light, Dame Bridget with a wig in her hand, and the Maids.)

LIGHT.

Here, Dame Bridget, enter.

WALTER. Is this the woman named to us, Clerk light?

LIGHT. This is Dame Bridget, yes, so please Your Grace.

WALTER. Well then, let us make haste to end the case.

Maids, take this out. Here.

1610

(Maids go out with glasses, etc.)

ADAM (while this is going on). Listen, Evie, now,

You roll that pill in proper style for me,

As should be done, and then this evening I

Will eat a carp with you to celebrate.

That rascal's got to swallow pill and all:

If it's too big to take, it may mean death.

WALTER (catches sight of the wig). What sort of wig is this Dame Bridget has

In hand?

LIGHT. Your Grace?

WALTER.

I asked what sort of wig

The woman has?

LIGHT.

$\mathrm{Hm}$ !

WALTER.

What?

LIGHT.

Beg pardon- 
WALTER. Will you speak up?

LIGHT.

If you will be so kind

As have the Judge put questions to the woman,

1620

It will appear to whom the wig belongs,

And other facts as well, I make no doubt.

WALTER. I do not care to know who owns the wig.

How did she get the wig? Where was it found?

LIGHT. The woman found the wig upon the trellis

1625

Near Martha Rull's abode. It hung there speared,

Just like a nest, amid the twining vines,

Beneath the window where the maiden sleeps.

MARTHA. What? By my house? My trellis?

WALTER (aside). Justice Adam,

If you have something to confide to me, 1630

I beg you, for the honor of the court,

Please be so kind and tell me now.

ADAM. What, $I$ tell you-?

WALTER.

Well? Have you not-?

ADAM.

(Adam seizes the wig.)

WALTER. This wig now, does it not belong to you?

ADAM. The wig here, gentlemen, is mine indeed!

1635

It is the very one, by thunder's light,

That I gave to this lad a week ago

To take for me to Master Flour in Utrecht.

WALTER. Whom? What?

LIGHT.

To Ruprecht?

RUPRECHT.

$\mathrm{Me}$ ?

ADAM.

When you, you rascal,

Went into Utrecht just a week ago, 1640

Did I not give this wig to you to take

And have the barber put it back in shape?

RUPRECHT. You ask-? Well yes. You gave me- 
ADAM. $\quad$ Speak then, why

Did you, you scoundrel, not deliver it?

Why didn't you, at my express command,

Go to the barber and hand in the wig?

RUPRECHT. Why did I not-God's lightning strike me dead!

I did go to the workshop with the wig.

And Master Flour, he took it-

ADAM.

Turned it in?

And now it's hanging there in Martha's trellis?

O wait, you scamp! You don't escape like that.

Behind all this I smell a rank disguise,

Some mutiny or the like-Your Grace permits

$\mathrm{Me}$ to interrogate this woman here?

WALTER. You say you gave this wig-?

1655

ADAM.

So please Your Grace,

When yonder fellow there, on Tuesday last,

Drove into Utrecht with his father's oxen,

He came into my office and he said,

"Have you an errand to be done in town?"

'My son,' says I, 'if you will be so good,

Then take this wig and have it renovated'-

I didn't say to him: go now and keep

The wig with you, disguise yourself in it

And leave it hanging in Dame Martha's trellis.

BRIDGET. Good sirs, your pardon, Ruprecht here, I think, 1665

Was not the one you want. For when last night

I went to the farm to see my cousin there,

She being hard in labor, in the yard

I heard the girl say scolding words, but soft,

For fear and fury seemed to take her voice.

1670

"Fie, shame on you, you despicable man,

What is this? Go! Or I will call my mother";

As if the Spaniards were inside the land.

Then: 'Eva!' through the fence I called her, 'Eva!

What is it? What's the matter?'-All is still:

'Well? Answer me!'-“Yes, aunt, what do you want?"

'What's going on?' I ask.-."What should there be?"

'Is Ruprecht there?'-“'Oh, that; Oh yes, it's Ruprecht. 
Just go your ways."-Thinks I, save your own hide. These youngsters love ais others scold and fight.

MARTha. And so-?

RUPRECHT. And so-?

WALTER. Hush! Let the woman finish.

BRIDGET. As I was coming back here from the farm, About the hour of midnight, and was just Beneath the limes, at Martha's garden there, A fellow whisks right past me, bald of pate; 1685 He has a horse's hoof, and after him It stinks like smoke and pitch and hair and sulfur. I speak a hasty prayer to God, and turn Around in horror, and I see, my soul, The bald spot, gentlemen, swiftly disappearing, Like rotten wood shine through the linden walk.

RUPRECHT. What! Thunder-ation!

MARTHA. Are you crazy, Bridget?

RUPRECHT. You think it was the Devil-?

LigHT. Hush!

BRIDGET. My soul,

I know right well just what I saw and smelled.

WALTER (impatient). I am not here to ferret out the Devil, 1695 But if 'twas he, he cannot be accused.

If you can name us any other, well:

But with that sinner leave us, please, in peace.

LIGHT. I beg Your Grace to let her end her tale.

WALTER. What crazy folk!

BRIDGET.

All right, as you command.

But here Clerk Light can testify for me.

WALTER. What? You a witness?

LIGHT.

In a manner, yes.

WALTER. In truth, I don't know- 
LIGHT. May I humbly beg

Not to disturb this woman in her story.

That 'twas the Devil I would not maintain, 1705

But as to the horse's hoof, and shiny pate, And smoke behind, if I'm not much mistaken, All that is quite correct! -Now then, proceed!

BRIDGET. Now when today I learned with much surprise What had occurred at Martha Rull's, and I, 1710

To ferret out the smasher of the jug,

Whom I'd encountered by the trellis there, Investigate the spot where out he leaped, I find a track, good sirs, right in the snowWhat sort of track, I ask you, do I find?

The right foot fine and sharp and neatly edged,

A human foot, as regular as any,

To left of it, misshapen, coarsely trampled,

A monstrous thing, a rounded horse's hoof.

WALTER (vexed). Oh, twaddle, crazy, damnable-!

VEIT. It isn't possible!

\section{BRIDGET. Upon my faith!}

Right by the trellis, where the leap was made,

Behold a circle wide, of trampled snow,

As if a sow had rolled around in it;

And human foot and horse's hoof and human foot and horse's hoof,

Off through the garden, out into the world.

ADAM. The deuce!-Why, did the rascal have the brass,

Disguised in devil's form-?

RUPRECHT.

LIGHT.
What! I!

Hush! Hush!

BRIDGET. The man who seeking a badger finds his trail, 1730

The hunter, doesn't triumph as I did.

'Say, Mr Clerk,' says I, for at that moment

I see the worthy man, sent me by you,

'Clerk Light,' says I, 'you can give up your trial.

The pitcher smasher you'll not bring to judgment,

He'll find no worser place to be than hell:

Here is the track that shows you how he went.' 
WALTER. And then did you convince yourself?

LIGHT.

Your Grace,

This track she had quite accurately described.

WALTER. A horse's hoof?

1740

Light. A human foot, so please you,

But praeter propter like a horse's hoof.

ADAM. My soul, good sirs, this seems a serious thing.

We've seen a lot of sharply written books

Which won't admit that there is any God;

No atheist has yet made valid proof,

1745

Not to my knowledge, that there is no devil.

The case before us seems then to deserve

Discussion speciai. So I would propose

Before we try to formulate a verdict,

We question first the Synod at the Hague,

Whether our court has warrant to assume

Beelzebub himself has smashed the jug.

WALTER. Such a proposal I'd expect from you.

What's your opinion, Mr. Clerk?

LIGHT.

Your Grace

Need not consult the Synod to decide.

1755

Complete-with your permission!-your report,

You there, Dame Bridget, please; the case will then

From circumstantial facts, I hope, be clear.

BRIDGET. On this: 'Now, Mr. Clerk,' says I, 'let us

Follow this track a little way, and see

To where the Devil may have got away.'

"“All right," says he, "Dame Bridget, good idea;

Perhaps we shall not go too far afield,

If we should go to Justice Adam's house."

WALTER. Well? And you found-?

BRIDGET.

Well, first of all we found

Beyond the garden in the linden lane,

The place where, sending out his sulfur fumes,

The Devil had run into me: a curve, 
As when a dog goes swerving to one side

To dodge a cat that spits into his face.

WALTER.

And then?

BRIDGET. Not far away there stands a monument

Close by a tree, that makes me start with fright.

WALTER. A monument? What?

BRIDGET.

What? Yes, you will be-

AdAM (aside). O damn, my bowels.

LIGHT.

Kindly pass that by.

Pass by that spot, I beg of you, Dame Bridget.

WALTER. I want to know just where the footsteps led!

BRIDGET. Where to? My faith, directly here to you,

Exactly as our Mr. Clerk has said.

Walter. To us? And here?

BRIDGET.

Straight from the linden lane

Upon the green, and then along the fishpond, 1780

Across the bridge, then traversing the churchyard.

And so, I say, to Justice Adam's house.

WALter. To Justice Adam's house?

ADAM.

Here to my house?

BRIDGET. That's what I said.

RUPRECHT.

The Devil surely would

Not live here in the court?

1785

BRIDGET.

Faith, I don't know

If he lives in this house; but it was here,

As I'm an honest woman, he turned in:

The track goes to the threshold at the rear.

ADAM. Could he perhaps have gone right through-?

BRIDGET. Or gone right through, indeed. May be. That's so.

The track in front- 
WALTER.

Was there a track in front?

LIGHT. In front, so please Your Grace, there was no track.

BRIDGET. In front of course the track was trampled down.

ADAM. Ah, trampled. Gone right through. I am a rogue.

This fellow, mark my words, has on the law

1795

Hung something there. I am no honest man

If nothing's rotten in the registry.

If my accounts, as now I do not doubt,

Turn out to be confused and in disorder,

Upon my word, I'll vouch for nothing now.

1800

WALTER. Nor I. (Aside.) Hm, hm! I wonder, was't the left, Or was't the right one? One of his two feet-

Judge Adam, please! Your snuffbox!-Be so good.

ADAM. The snuffbox?

WALTER Snuffbox. Hand it here!

ADAM (to Light). You take it, Clerk.

WALTER. Oh, why so formal? Just a step it takes.

1805

ADAM. No, that's all right. You take it to His Grace.

WALTER. I would have whispered something in your ear.

ADAM. Perhaps we'll later have a chance-

WALTER.

All right.

(After Light has sat down again.)

Tell me, is there some person in the village

Who has misshapen feet?

Light. Hm! Well, there is indeed a man in Huysum-

WALTER. Oh? Who?

LIGHT.

Well, if Your Grace will ask the Judge-

WALTER. You mean Judge Adam?

ADAM.

I've no information.

Ten years I've been in office here in Huysum,

And to my knowledge everyone is sound.

WALTER (to Light). Well? Whom have you in mind? 
MARTHA. Oh, keep your feet outside!

Why stick them thus disturbed beneath the table, To make one think you'd made that track yourself?

WALTER. Who then? You mean Judge Adam?

ADAM. I? That track?

Am I Old Nick? Is that a horse's hoof? (He shows his left foot.)

WALTER. Upon my word. That foot is good. (Aside to Adam.)

Now put an end at once to the proceedings.

ADAM. And if the Devil had a foot like this

He could go out to balls and dance his fill.

MARTha. I say so too. How should our Village Judge- 1825

ADAM. Oh, bosh! I!

WALTER.

Make an end at once, I say.

BRIDGET. The only problem left, my worthy sirs,

Is, as it seems, this solemn decoration.

ADAM. What sort of solemn-?

BRIDGET.

Here, this wig I hold!

Who ever saw such a costume on the Devil?

A towering structure, teeming more with tallow

Than any Dean's in a cathedral pulpit!

ADAM. We rustic folks have but imperfect knowledge,

Dame Bridget, of the fashions down in hell.

They say he wears his own hair commonly.

1835

But on earth, I am convinced of that,

He flings a wig upon his head, in order

To mingle unobserved with dignitaries.

WALTER. O villain! Worthy to be publicly

Chased from the bench in shame! What saves you here,

Is nothing but the honor of the court.

Conclude the session now!

ADAM.

I hope you don't-

WALTER. Your hope is vain. Withdraw as best you can. 
ADAM. You think that I, the Judge, I, yesterday,

Forsook my wig among Dame Martha's vines?

WALTER. No, God forbid! For yours went up in smoke,

Like Sodom and Gomorrha, you recall.

LIGHT. Or rather-pardon me, Your Grace! the cat

It was that littered in it yesterday.

ADAM. Good sirs, and though appearances condemn me: 1850

Don't be too hasty, I beseech. At stake

For me is honor or the worst disgrace.

And while the girl keeps silent, I don't see

What right you have to put the blame on me.

I sit here on the judge's bench at Huysum,

1855

And here I lay this wig upon the table:

The one who claims this wig belongs to me

I'll summon to the highest court in Utrecht.

LIGHT. Hm! Well, the wig will fit you, on my soul,

As if it had grown upon your very pate. (He puts the wig on Adam.)

ADAM. A slander!

Light. No?

ADAM. As cloak about my shoulders

'Twould be too big, say nothing of my head. ( $\mathrm{He}$ surveys himself in the mirror.)

RUPRECHT. Oh, such a thundering rascal!

WALTER.

Quiet, you!

MARTHA. Oh, such a curséd, lightning-smitten judge!

WALTER. Once more, will you, shall I conclude the case? 1865

ADAM. What is your order?

RUPRECHT (to Eve). Eve, is he the one?

WALTER. What does this impudence presume to say?

VEIT. Keep still, I say.

ADAM. Wait, brute, I'll get you yet.

RUPRECHT. Oh, you damned horse's hoof! 
WALTER. Hi there! the bailiff !

VeIT. Shut up, I say.

RUPRECHT. You wait! Today I'll reach you.

Today you'll throw no sand into my eyes.

WALTER. Have you not sense enough-?

ADAM. Well, if Your Grace

Permits, I will pronounce the sentence now.

Walter. Good. Do. Pronounce it.

ADAM.

Now the case is clear,

And Ruprecht there, the scoundrel, is the culprit. 1875 WALTER. That's good. Go on.

ADAM.

His neck goes into irons,

And since he has most disrespectfully

Behaved as touching me, his Judge,

I'll throw him into prison behind bars,

For just how long I shall determine later.

1880

Eve. What, Ruprecht—?

RUPRECHT.

Me to prison?

Eve.

And in irons?

WALTER. Don't be alarmed, my children. -Are you done?

ADAM. He may replace the jug, or he may not.

WALTER. All right. This session now is at an end.

And Ruprecht will appeal his case to Utrecht.

Eve. What, he, you say he must appeal in Utrecht?

RUPRECHT. What. I-?

WALTER.

Deuce take it, yes! And till that time-

EvE. And till that time-?

RUPRECHT. I have to go to jail?

Eve. His neck in irons? Are you judges, you?

It's he, that shameless one, he sitting there,

$\mathrm{He}$ was the one- 
WALTER. You hear me, damn it! Silence!

Till then no harm will come to him-

Eve.

Up, Ruprecht!

Judge Adam was the man who smashed the jug!

RUPRECHT. Oh, wait, you!

MARTHA.

$\mathrm{He}$ ?

BRIDGET.

That man?

Eve. Yes, he! Up, Ruprecht!

He visited your Eva yesterday!

Up! Seize him! Throw him down now as you will.

WALTER (rises). Stop there! The one who breaks the peaceEve.

All one!

You've earned the irons, Ruprecht, go!

Go, throw him down from off the judge's bench.

ADAM. Your leave, good sirs. (He starts out.)

E'VE.

Here! Up!

RUPRECHT.

Stop!

EvE.

$$
\text { Quickly! }
$$

ADAM.

What?

RUPRECHT. Damned, limping devil!

EVE.

Got him?

RUPRECHT. Hell and sulfur!

I've only got his cloak!

WALTER.

Go! Call the bailiff!

RUPRECHT (strikes the cloak).

Biff! That is one. And biff! and biff! One more.

Again! Since I can't reach his crooked back.

WALTER. Unruly churl! -Restore the Court to order. 1905

-If you are not immediately quiet,

The irons will be yours this very day.

VEIT. Be quiet, you confounded rogue. 


\section{SCENE TWELVE}

(All move down stage.)

RUPRECHT.

How shamefully I injured you today!

Oh, Evie!

God's thunder and his lightning; and last night!

1910

$O$ you my darling girl, love of my heart!

Will you forgive me ever while you live?

EvE (casts kerself at Walter's feet).

Sir, if you do not help us, we are lost!

WALTER. Why lost? How so?

RUPRECHT.

Good God! What is the matter?

Eve. O, save my Ruprecht from conscription, sir!

1915

For see, this levy-and it was Judge Adam

Confided this to me as very secret,

Goes to the Indies; and from there, you know,

Out of three men but one comes back again!

WALTER. What! To the Indies! Are you in your senses? 1920

Eve. To Bantam, yes, Your Honor; don't deny it!

Here is the letter, with its very private

Instructions as concerning the militia,

Just lately issued by the government:

You see, I am informed on every point.

1925

WALTER (takes the letter and reads it).

$O$ what a monstrous guile and base deceit!-

The letter's false!

Eve.

False?

WALTER.

False, upon my life!

Clerk Light, now speak and say if that's the order

Which recently was sent to you from Utrecht.

LIGHT. The order! What! The sinner! It's a scribble

Which he has written out with his own hand!-

The troops to be recruited are intended

For service in this country; not a soul

That dreams of shipping them out to the Indies! 
EvE. No, really not, dear sirs?

1935

WALTER.

Upon my faith.

And as a proof of what I say: this Ruprecht,

If it were as you say: I'll buy him free!

Eve (rises). O heaven! How the villain lied to me!

For just with all this fearful apprehension

He tortured me and came to me at night

1940

To force on me a lying affidavit;

Proving that his false witness of disease

Could free the lad from military service;

Explained it and assured me, and he slipped,

To fill the papers out, into my room:

1945

Demanding there such shameful things of me

As maiden lips would never dare to say!

BRIDGET. Oh, what a villainous and vile deceiver!

RUPRECHT. Forget the horse's hoof, my darling girl!

For if a horse had smashed the jug for you,

I'd be as jealous as I am right now!

(They kiss.)

VEIT. And so say I! Kiss and be reconciled;

At Whitsun, if you like, we'll have the wedding!

IIGHT (at the window). Just see how Justice Adam, look, I beg you,

Up hill, down dale, stumps through the fallow fields 1955

As if for rapid flight from wheel and gallows!

WALTER. What? Is that Justice Adam?

LIGHT.

Certainly!

SEVERAL. There, now he's got upon the road, look, look!

See how the wig is whipping on his back!

WALTER. Run quick, Clerk Light, and bring him back again!

Keep him from making evil matters worse.

$\mathrm{He}$ is suspended from his office, yes,

And I appoint you, pending further word

Of notice, to administer the same; 
But if his funds are straight, as much I hope,

I would not then compel him to desertion.

Go then! Do me this favor, bring him back!

(Light goes out.)

\section{LAST SCENE}

MARTHA. I beg you, Gracious Sir, where shall I find

The seat of government in Utrecht town?

Walter. And why, Dame Martha?

MARTHA (bridling). Hm! And why? Oh well-

Shall then my jug not find some justice there?

WALTER. Forgive me! To be sure. On the great square

On Tuesdays and on Fridays court is held.

Martha. That's good! This day week I'll present myself.

(All go out.) 



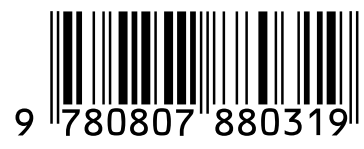

